\title{
New Low-Melting Triply Charged Homoleptic Cr(III)-Based Ionic Liquids in Comparison to Their Singly Charged Heteroleptic Analogues
}

\author{
Tim Peppel ${ }^{1, * \mathbb{D}}$ and Martin Köckerling ${ }^{2,3}$ \\ 1 Leibniz-Institut für Katalyse e.V. (LIKAT), Heterogene Photokatalyse, Albert-Einstein-Str. 29a, \\ 18059 Rostock, Germany \\ 2 Institut für Chemie, Anorganische Festkörperchemie, Universität Rostock, Albert-Einstein-Str. 3a, \\ 18059 Rostock, Germany; martin.koeckerling@uni-rostock.de \\ 3 Department Life, Light and Matter, Universität Rostock, 18051 Rostock, Germany \\ * Correspondence: tim.peppel@catalysis.de
}

Citation: Peppel, T.; Köckerling, M. New Low-Melting Triply Charged Homoleptic Cr(III)-Based Ionic Liquids in Comparison to Their Singly Charged Heteroleptic Analogues. Materials 2021, 14, 2676. https://doi.org/10.3390/ma14102676

Academic Editors: Renata Costa and Carlos Pereira

Received: 26 March 2021

Accepted: 11 May 2021

Published: 20 May 2021

Publisher's Note: MDPI stays neutral with regard to jurisdictional claims in published maps and institutional affiliations.

Copyright: ( $\odot 2021$ by the authors Licensee MDPI, Basel, Switzerland. This article is an open access article distributed under the terms and conditions of the Creative Commons Attribution (CC BY) license (https:// creativecommons.org/licenses/by/ $4.0 /)$.

\begin{abstract}
A series of new low-melting triply charged homoleptic $\mathrm{Cr}$ (III)-based ionic liquids of the general formula $(R \mathrm{MIm})_{3}\left[\mathrm{Cr}(\mathrm{NCS})_{6}\right](R=$ methyl, ethyl, $n$-butyl, benzyl) is reported. Their syntheses and properties are described in comparison to their singly charged heteroleptic analogues of the general formula (RMIm) $\left[\mathrm{Cr}(\mathrm{NCS})_{4} L_{2}\right](R=$ methyl, ethyl, $n$-butyl, benzyl; $L=$ pyridine, $\gamma$-picoline). In total, sixteen new Reineckate related salts with large imidazolium cations are described. Out of these, five compounds were crystallized, and their structures determined by single-crystal X-ray structure analyses. They all consisted of discrete anions and cations with octahedrally coordinated $\mathrm{Cr}$ (III) ions. In the structures, various hydrogen contacts interconnect the entities to build up hydrogen bonded networks. Thermal investigations showed relatively low melting points for the homoleptic complexes. The compounds with the $\left[\mathrm{Cr}(\mathrm{NCS})_{6}\right]^{3-}$ anion melt without decomposition and are stable up to $200 \mathrm{~K}$ above their melting points. The complex salts with the $\left[\mathrm{Cr}(\mathrm{NCS})_{4} L_{2}\right]^{-}$anion, in contrast, start to decompose and lose $L$ molecules (Pyr or Pic) already at the melting point.
\end{abstract}

Keywords: chromium; ionic liquids; crystal structure; physical properties; melting point

\section{Introduction}

For more than 30 years, ionic liquids (ILs), designated as organic salts with melting points below $100^{\circ} \mathrm{C}$, have been a broad field of investigation due to their in part unique properties. They exhibit, for instance, large electrochemical windows, liquid ranges, hardly measurable vapor pressures, special solubility characteristics, and applications in catalysis [1-5]. ILs have been often called "designer solvents" and have been used in research fields fitting into the "Green Chemistry" approach. Due to their low vapor pressures at room temperature, they are used as substitutes for common organic solvents. In addition, they exhibit partly exceptional solubility properties for organic, inorganic as well as metalorganic compounds. ILs play an important role as starting materials for N-heterocyclic carbenes (NHCs), which can be applied in a variety of different catalytic reactions [6-8].

With the introduction of transition metals into ILs, so-called magnetic ionic liquids (MILs) can be prepared. Currently, these ILs containing metal-based paramagnetic complex ions are a highly investigated subclass because they show magnetic response in addition to the phenomena above-mentioned [9-13]. Furthermore, they have been thoroughly investigated as systems assumed to be magnetic and magnetorheological fluids $[14,15]$.

Solid state investigations of MILs by means of single crystal X-ray diffraction techniques have been applied for $3 \mathrm{~d}, 4 \mathrm{~d}, 5 \mathrm{~d}$, and lanthanide metal-containing systems, respectively. For the subclass of $3 \mathrm{~d}$ metal-based magnetic ILs, most molecular structures are known for Co (e.g., $(R \mathrm{MIm})_{2}\left[\mathrm{CoX}_{4}\right], R=$ ethyl, n-butyl; $\mathrm{MIm}=\mathrm{N}$-methylimidazolium; $\mathrm{X}=\mathrm{Cl}, \mathrm{Br}$ ) [16-20], 
$\mathrm{Ni}$ (e.g., $(R \mathrm{MIm})_{2}\left[\mathrm{NiCl}_{4}\right], R=$ ethyl, n-butyl) [16-18], $\mathrm{Cu}$ (e.g., $(R \mathrm{MIm})_{2}\left[\mathrm{Cu}_{\mathrm{n}} X_{\mathrm{m}}\right], \mathrm{n}=1$, $\mathrm{m}=4: R=$ n-butyl, $\mathrm{n}$-dodecyl; $X=\mathrm{Cl} ; \mathrm{n}=3, \mathrm{~m}=8: R=$ n-butyl; $X=\mathrm{Cl})[17,21,22]$, $\mathrm{Fe}$ (e.g., $(R \mathrm{MIm})_{2}\left[\mathrm{FeCl}_{4}\right], \mathrm{R}=\mathrm{n}$-butyl) [17], and $\mathrm{Zn}$ (e.g., $(R \mathrm{MIm})_{2}\left[\mathrm{ZnX} \mathrm{X}_{2} \mathrm{Y}_{2}\right], X=Y=\mathrm{Cl}$; $R=$ n-butyl; $X=\mathrm{Cl}, Y=\mathrm{Br} ; R=$ methyl) $[17,23]$. The majority of these types of systems contain halide ligands in the complex anions, whereas pseudohalide ligands are scarcely used. The most often used cations are either 1-ethyl-3-methylimidazolium (EMIm) or 1-butyl-3-methylimidazolium (BMIm). Therefore, the melting points of such compounds are far beyond $100^{\circ} \mathrm{C}$.

Over the last decade, we have reported structural information on different series of low-melting imidazolium-based transition MILs. These include $3 \mathrm{~d}$ metal-based complexes containing Co (e.g., $(R \operatorname{Im})_{2}\left[\mathrm{CoBr}_{4}\right], R=1$-butyl-3-methylimidazolium, 1,3-dibutyl2,4,5-trimethylimidazolium; $(R \mathrm{MIm})_{2}\left[\mathrm{Co}(\mathrm{NCX})_{4}\right], R=$ methyl, ethyl, $\mathrm{X}=\mathrm{O}$, S; and $(R M I m)\left[\mathrm{CoBr}_{3}\right.$ quin], $R$ = ethyl, n-butyl, $\mathrm{n}$-hexyl, $\mathrm{n}$-nonyl, quin = quinoline) [24-27], $\mathrm{Ni}$ (e.g., $(R \operatorname{Im})_{2}\left[\mathrm{NiBr}_{4}\right], R=1$,3-dibutyl-2,4,5-trimethylimidazolium; and $(R \mathrm{MIm})\left[\mathrm{NiBr}_{3} L\right]$, $R=$ ethyl, $L=\mathrm{N}$-methylimidazole, $\mathrm{N}$-methylbenzimidazole, quinoline, $\left.\mathrm{PPh}_{3}\right)[27,28], \mathrm{Mn}$ (e.g., polymeric (RMIm) $\left[\mathrm{Mn}(\mathrm{NCS})_{3}\right], R=$ ethyl; and (DMDIm) $\left[\mathrm{Mn}(\mathrm{NCS})_{4}\right], \mathrm{DMDIM}=3,3^{\prime}-$ methylenbis(1-methyl-imidazolium)) [29,30], and $\mathrm{Cr}$ (e.g., $(R \mathrm{MIm})\left[\mathrm{Cr}(\mathrm{NCS})_{4} L_{\mathrm{x}}\right], R=$ ethyl, nbutyl, $\mathrm{x}=1: L=$ phenanthroline, 2,2'-bipyridine, $\mathrm{x}=2: L=\mathrm{NH}_{3}$ ) [31-33]. These materials have been synthesized in order to lower the melting point of such substances and to investigate their properties with respect to ionic liquids (ILs).

Salts with high melting points containing Reineckate and analogue anions (Reinecke's salt, $\left.\left(\mathrm{NH}_{4}\right)\left[\mathrm{Cr}(\mathrm{NCS})_{4}\left(\mathrm{NH}_{3}\right)_{2}\right] \cdot \mathrm{H}_{2} \mathrm{O}\right)$ have been known in the literature for at least 160 years [34-36], and have been investigated as chemical actinometers, substances for quantum yield determinations, compounds in charge-transfer photochemistry, and in the analysis of medical products [37-40]. In particular, complexes exhibiting $\left[\mathrm{Cr}(\mathrm{NCS})_{4} L\right]^{-}$ anions $[L=1,10$-phenanthroline (phen) or 2,2'-bipyridine (bipy) $]$ have been used, for example, in the analytical determination of alkaloids, in the analytical determination of bismuth, and as promising magnetic charge transfer salts [41-43].

In this contribution, we extend the series of Reineckate-analogue compounds to triply charged homoleptic as well as singly charged heteroleptic complexes of the general formula $(R M I m){ }_{x}\left[\mathrm{Cr}(\mathrm{NCS})_{4} L_{2}\right](R=$ methyl, ethyl, n-butyl, benzyl; MIm = N-methylimidazolium; $\mathrm{x}=3: L=$ NCS; $\mathrm{x}=1: L=$ Pyr, Pic; Pyr = pyridine; Pic $=\gamma$-picoline $=4$-methylpyridine). We report on the syntheses, properties, and structures of these three series of imidazoliumbased salts. In total, of five substances, crystal and molecular structures were determined by single-crystal X-ray diffraction: $(\mathrm{DMIm})_{3}\left[\mathrm{Cr}(\mathrm{NCS})_{6}\right],(\mathrm{EMIm})_{3}\left[\mathrm{Cr}(\mathrm{NCS})_{6}\right]$, $(\text { BenzMIm })_{3}\left[\mathrm{Cr}(\mathrm{NCS})_{6}\right],(\mathrm{BMIm})\left[\mathrm{Cr}(\mathrm{NCS})_{4}(\mathrm{Pyr})_{2}\right]$, and $(\mathrm{EMIm})\left[\mathrm{Cr}(\mathrm{NCS})_{4}(\mathrm{Pic})_{2}\right]$, respectively. In addition, all substances were investigated by means of UV/vis and infrared spectroscopy, thermogravimetric analyses (TGA), and differential scanning calorimetry (DSC).

\section{Materials and Methods}

\subsection{Instrumentation}

Elemental analysis for $\mathrm{C}, \mathrm{H}, \mathrm{N}$, and $\mathrm{S}$ was performed on a TruSpec ${ }^{\circledR \circledR}$ Micro device (Leco, St. Joseph, MI, USA). The MIR (MIR = mid-infrared) spectra were recorded by the attenuated total reflectance (ATR) technique on a Bruker Alpha FTIR spectrometer (Bruker Corporation, Billerica, MA, USA) in the region 4000-600 $\mathrm{cm}^{-1}$. UV-Vis spectra were recorded on a Lambda 365 device (PerkinElmer, Waltham, MA, USA) in the diffuse reflectance mode for powders or in absorbance mode for solutions. Selective melting points were determined by differential scanning calorimetry (DSC) measurements with a DSC 1 instrument (Mettler-Toledo, Columbus, OH, USA) in the range -60 to $100{ }^{\circ} \mathrm{C}$ at a heating rate of $10 \mathrm{~K} \mathrm{~min}^{-1}$ (Ar atmosphere, Al crucible) or STA 449 F3 Jupiter device (Netzsch, Selb, Germany) in the range 25 to $600{ }^{\circ} \mathrm{C}$ at a heating rate of $10 \mathrm{~K} \mathrm{~min}^{-1}\left(\mathrm{~N}_{2}\right.$ atmosphere, $\mathrm{Al}$ crucible). Single-crystal X-ray diffraction measurements were made with an Apex X8 diffractometer (Bruker-Nonius, Billerica, MA, USA) equipped with a CCD detector. The measurements were performed with monochromatic Mo-K $\alpha$ radiation $(\lambda=0.71073 \AA)$. 
The preliminary unit-cell data were obtained from the reflection positions of 36 frames, measured in different directions of reciprocal space. After the completion of the data measurements, the intensities were corrected for Lorentz and polarization effects with the Bruker-Nonius software [44]. Absorption corrections were applied by using the multi-scan method as implemented in SADABS [45].

The structure solutions and refinements were performed with the SHELX program package (vers. 2014) [46]. All non-hydrogen atoms were refined anisotropically. The hydrogen atoms were added at idealized positions and refined in riding models. These data can be obtained free of charge from the Cambridge Crystallographic Data Center: CCDC 1988743 for (DMIm) $)_{3}\left[\mathrm{Cr}(\mathrm{NCS})_{6}\right]$, CCDC 1988745 for (EMIm) $)_{3}\left[\mathrm{Cr}(\mathrm{NCS})_{6}\right], \mathrm{CCDC}$ 1988741 for $(\text { BenzMIm) })_{3}\left[\mathrm{Cr}(\mathrm{NCS})_{6}\right], \mathrm{CCDC} 1988742$ for $(\mathrm{BMIm})\left[\mathrm{Cr}(\mathrm{NCS})_{4}(\mathrm{Pyr})_{2}\right]$, and CCDC 1988744 for (EMIm) $\left[\mathrm{Cr}(\mathrm{NCS})_{4}(\mathrm{Pic})_{2}\right]$.

\subsection{Materials}

All commercially available chemicals were used as received (Sigma-Aldrich, St. Louis, MO, USA, purities > 99\%). N-methylimidazole was freshly distilled from $\mathrm{KOH}$ in vacuo before use. Ionic liquid precursors were prepared by procedures in the literature [47-51]. $\mathrm{K}_{3}\left[\mathrm{Cr}(\mathrm{NCS})_{6}\right]$ was synthesized on a multi-gram scale [32,52,53]: A $100 \mathrm{~mL}$ aqueous solution of $5.0 \mathrm{~g}(0.01 \mathrm{~mol})$ chrome alum (chromium(III) potassium sulfate dodecahydrate, $\left.\mathrm{KCr}\left(\mathrm{SO}_{4}\right)_{2} \cdot 12 \mathrm{H}_{2} \mathrm{O}\right)$, and $5.8 \mathrm{~g}(0.06 \mathrm{~mol}) \mathrm{KSCN}$ was evaporated to dryness. The residue was extracted exhaustively with ethyl acetate and the resulting solution was evaporated to dryness again. The product $\mathrm{K}_{3}\left[\mathrm{Cr}(\mathrm{NCS})_{6}\right]$ was obtained as a red-violet solid after final drying at $140{ }^{\circ} \mathrm{C}$ in vacuum in high yield as a hygroscopic solid (4.7 $\left.\mathrm{g}, 90 \%\right)$; elemental analysis for $\mathrm{C}_{6} \mathrm{CrK}_{3} \mathrm{~N}_{6} \mathrm{~S}_{6} \cdot 0.5 \mathrm{H}_{2} \mathrm{O}$ (calcd). C 13.7 (13.7), H 0.2 (0.2), N 16.0 (16.0), S 36.0 (36.5); IR $\left(v_{\max }, \mathrm{cm}^{-1}\right): 2083 v(\mathrm{CN}), 478 \delta(\mathrm{NCS})$.

\subsection{Synthesis of $(\mathrm{RMIm})_{3}\left[\mathrm{Cr}(\mathrm{NCS})_{6}\right]$}

Samples of the general formula $(R \mathrm{MIm})_{3}\left[\mathrm{Cr}(\mathrm{NCS})_{6}\right](R=$ methyl, ethyl, $\mathrm{n}$-butyl, benzyl; $\mathrm{MIm}=$ methyl-imidazolium) were prepared via direct salt metathesis reaction of $3.0 \mathrm{eq}$. $(R M I m) X(X=\mathrm{Cl}, \mathrm{Br}, \mathrm{I} ; 3.0 \mathrm{mmol})$ and 1.0 eq. $\mathrm{K}_{3}\left[\mathrm{Cr}(\mathrm{NCS})_{6}\right](0.5 \mathrm{~g} ; 1.0 \mathrm{mmol})$ in $50 \mathrm{~mL}$ acetone with stirring at ambient conditions for $24 \mathrm{~h}$. The precipitate was filtered off and the filtrate solution was evaporated to dryness in vacuum. The residue was dissolved in either dichloromethane or acetone/ethyl acetate $(v: v=2: 1)$, filtered, and evaporated to dryness in vacuum again. The final products were recrystallized by dissolution in small amounts of acetone, followed by subsequent precipitation by the slow addition of water. The solids were filtered off, washed thoroughly with water and n-hexane, and finally dried in vacuum. The final products were obtained as red-violet substances in high yields ( $>90 \%)$.

(DMIm) $)_{3}\left[\mathrm{Cr}(\mathrm{NCS})_{6}\right]$ : Prepared using DMImI [51]. Red-violet solid, yield 75\%. M.p. $138{ }^{\circ} \mathrm{C}$, solid-solid transition: $138{ }^{\circ} \mathrm{C}$; elemental analysis for $\mathrm{C}_{21} \mathrm{H}_{27} \mathrm{CrN}_{12} \mathrm{~S}_{6}$ (calcd.): $\mathrm{C} 35.2$ (36.5), H 4.0 (3.9), N 24.4 (24.3), S 27.8 (27.8); IR ( $\left.v_{\max }, \mathrm{cm}^{-1}\right): 2065 v(\mathrm{CN}), 826 v(\mathrm{CS}), 481$ $\delta(\mathrm{NCS}) ; \mathrm{UV} / \mathrm{Vis}\left(\lambda_{\max }, \mathrm{nm} ; 23^{\circ} \mathrm{C}\right): 413,552$ (powder); 416, 556 (acetone).

$(\mathrm{EMIm})_{3}\left[\mathrm{Cr}(\mathrm{NCS})_{6}\right]$ : Prepared using commercially available EMImCl. Red-violet solid, yield 91\%. M.p. $84{ }^{\circ} \mathrm{C}$; elemental analysis for $\mathrm{C}_{24} \mathrm{H}_{33} \mathrm{CrN}_{12} \mathrm{~S}_{6}$ (calcd.): $\mathrm{C} 39.1$ (39.3), H 4.5 (4.5), N 22.9 (22.9), S 26.2 (26.2); IR ( $\left.v_{\max }, \mathrm{cm}^{-1}\right)$ : $2068 v(\mathrm{CN}), 837 v(\mathrm{CS}), 480 \delta(\mathrm{NCS})$; $\mathrm{UV} / \mathrm{Vis}\left(\lambda_{\max }, \mathrm{nm} ; 23^{\circ} \mathrm{C}\right): 413,552$ (powder); 416, 556 (acetone).

(BMIm) ${ }_{3}\left[\mathbf{C r}(\mathrm{NCS})_{6}\right.$ ]: Prepared using BMImCl [48]. Red-violet solid, yield 95\%. M.p. $45^{\circ} \mathrm{C}$; elemental analysis for $\mathrm{C}_{30} \mathrm{H}_{45} \mathrm{CrN}_{12} \mathrm{~S}_{6}$ (calcd.): C 44.4 (44.0), H 6.5 (5.5), N 20.3 (20.5), S 22.5 (23.5); IR ( $\left.v_{\max }, \mathrm{cm}^{-1}\right): 2064 v(\mathrm{CN}), 827 v(\mathrm{CS}), 482 \delta(\mathrm{NCS}) ; \mathrm{UV} / \mathrm{Vis}\left(\lambda_{\max }, \mathrm{nm} ; 23^{\circ} \mathrm{C}\right)$ : 413, 552 (powder); 416, 556 (acetone).

(BenzMIm) ${ }_{3}\left[\mathbf{C r}(\mathbf{N C S})_{6}\right.$ ]: Prepared using BenzMImBr [47,54]. Red-violet solid, yield 97\%. M.p. $124{ }^{\circ} \mathrm{C}$; elemental analysis for $\mathrm{C}_{39} \mathrm{H}_{39} \mathrm{CrN}_{12} \mathrm{~S}_{6}$ (calcd.): $\mathrm{C} 51.0$ (50.9), H 4.2 (4.3), N 18.6 (18.3), S 20.8 (20.9); IR ( $\left.v_{\max }, \mathrm{cm}^{-1}\right)$ : $2072 v(\mathrm{CN}), 819 v(\mathrm{CS}), 480 \delta(\mathrm{NCS})$; UV/Vis $\left(\lambda_{\max }, \mathrm{nm} ; 23^{\circ} \mathrm{C}\right): 413,552$ (powder); 416, 556 (acetone). 


\subsection{Synthesis of (RMIm) $)_{3}\left[\mathrm{Cr}(\mathrm{NCS})_{4} L_{2}\right]$}

Samples of the general formula $(R M I m)_{3}\left[\mathrm{Cr}(\mathrm{NCS})_{4} L_{2}\right](R=$ methyl, ethyl, $\mathrm{n}$-butyl, benzyl; MIm $=$ methyl-imidazolium; $L=\mathrm{Pyr}=$ pyridine, $\mathrm{Pic}=\gamma$-picoline $=4$-methylpyridine $)$ were prepared via treatment of $\mathrm{K}_{3}\left[\mathrm{Cr}(\mathrm{NCS})_{6}\right]$ in excessive ligand Pyr or Pic $[55,56]$ to generate substances of the general formula $L \mathrm{H}\left[\mathrm{Cr}(\mathrm{NCS})_{4} L_{2}\right]$, followed by the transformation into the corresponding silver salts $\mathrm{Ag}\left[\mathrm{Cr}(\mathrm{NCS})_{4} L_{2}\right] .1 .0$ eq. $(R \mathrm{MIm}) X(X=\mathrm{Cl}, \mathrm{Br}, \mathrm{I}$; $2.6 \mathrm{mmol})$ and 1.0 eq. $\mathrm{Ag}\left[\mathrm{Cr}(\mathrm{NCS})_{4} L_{2}\right]$ were stirred at ambient conditions for $24 \mathrm{~h}$ in $100 \mathrm{~mL}$ of acetone. The resulting suspension was filtered from $\operatorname{AgX}(X=\mathrm{Cl}, \mathrm{Br}, \mathrm{I})$, precipitated, and the solvent was removed in vacuum. The residue was dissolved in acetone/ethyl acetate $(v: v=2: 1)$, filtered, and evaporated to dryness in vacuum again. The final products were recrystallized by dissolution in small amounts of acetone followed by subsequent precipitation by the slow addition of water. The solid were filtered off, washed thoroughly with water and $\mathrm{n}$-hexane, and finally dried in vacuum. The final products were obtained as red, hygroscopic substances in moderate yields.

PyrH $\left[\mathrm{Cr}(\mathrm{NCS})_{4}(\mathbf{P y r})_{2}\right]$ : Dried $\mathrm{K}_{3}\left[\mathrm{Cr}(\mathrm{NCS})_{6}\right](12.0 \mathrm{~g}, 23.2 \mathrm{mmol})$ was suspended in pyridine $(11.0 \mathrm{~g}, 139.0 \mathrm{mmol})$ and stirred for $4 \mathrm{~h}$ at $115^{\circ} \mathrm{C}$ in a sealed flask. After cooling to room temperature, the precipitate was washed with portions of acetic acid $(10 \%$ aqueous solution, $100 \mathrm{~mL}$ ) and water. Afterward, the precipitate was dissolved in acetone/ethyl acetate $(v: v=1: 1,200 \mathrm{~mL})$ and the solution was combined with an aqueous $\mathrm{NH}_{4} \mathrm{Cl}$ solution ( $20 \mathrm{~g}$ in $100 \mathrm{~mL} \mathrm{H}_{2} \mathrm{O}$ ) and brought to reflux. The resulting solution was evaporated to dryness in vacuum and the precipitate was extracted with acetone. The combined acetonic solutions were evaporated to dryness in vacuum and the resulting red solid was finally dried for several hours in vacuum at $120{ }^{\circ} \mathrm{C}(11.4 \mathrm{~g}, 94 \%)$. IR $\left(v_{\max }, \mathrm{cm}^{-1}\right)$ : $2051 \mathrm{v}(\mathrm{CN})$, $482 \delta$ (NCS).

$\mathbf{A g}\left[\mathbf{C r}(\mathbf{N C S})_{4}(\mathbf{P y r})_{2}\right]: \mathrm{PyrH}\left[\mathrm{Cr}(\mathrm{NCS})_{4}(\mathrm{Pyr})_{2}\right](5.0 \mathrm{~g}, 9.6 \mathrm{mmol})$ was dissolved in $100 \mathrm{~mL}$ acetone and slowly added to $200 \mathrm{~mL}$ of a vigorously stirred aqueous solution of $\mathrm{AgNO}_{3}$ $(4.9 \mathrm{~g}, 28.7 \mathrm{mmol})$. The resulting precipitate was filtered off, washed excessively with $\mathrm{H}_{2} \mathrm{O}$, $\mathrm{H}_{2} \mathrm{O}$ /acetone $(v: v=1: 1)$ and acetone, and finally dried in vacuum at room temperature for several hours, yielding a light red solid $(5.2 \mathrm{~g}, 98 \%)$. IR $\left(v_{\max }, \mathrm{cm}^{-1}\right): 2078 v(\mathrm{CN})$, $472 \delta$ (NCS).

(DMIm) $\left[\mathrm{Cr}(\mathrm{NCS})_{4}(\mathrm{Pyr})_{2}\right.$ ]: Prepared from DMImI [51] and $\mathrm{Ag}\left[\mathrm{Cr}(\mathrm{NCS})_{4}(\mathrm{Pyr})_{2}\right]$. Red hygroscopic solid, yield $52 \%$. M.p. $>180^{\circ} \mathrm{C}$ (dec.); elemental analysis for $\mathrm{C}_{19} \mathrm{H}_{19} \mathrm{CrN}_{8} \mathrm{~S}_{4} \cdot \mathrm{H}_{2} \mathrm{O}$ (calcd.): C 41.0 (40.9), H 3.4 (3.8), N 18.7 (20.1), S 20.5 (23.0); IR $\left(v_{\max }, \mathrm{cm}^{-1}\right)$ : $2056 v(\mathrm{CN})$, $837 \gamma(\mathrm{CS}), 483 \delta(\mathrm{NCS}) ; \mathrm{UV} / \mathrm{Vis}\left(\lambda_{\max }, \mathrm{nm} ; 23^{\circ} \mathrm{C}\right): 535$ (powder); 543 (acetone).

(EMIm) $\left[\mathrm{Cr}(\mathrm{NCS})_{4}(\mathbf{P y r})_{2}\right.$ ]: Prepared from commercially available EMImCl and $\mathrm{Ag}\left[\mathrm{Cr}(\mathrm{NCS})_{4}(\mathrm{Pyr})_{2}\right]$. Red hygroscopic solid, yield $78 \%$. M.p. $191{ }^{\circ} \mathrm{C}$ (dec.); elemental analysis for $\mathrm{C}_{20} \mathrm{H}_{21} \mathrm{CrN}_{8} \mathrm{~S}_{4} \cdot \mathrm{H}_{2} \mathrm{O}$ (calcd.): C 41.6 (42.0), $\mathrm{H} 4.2$ (4.1), $\mathrm{N} 19.7$ (19.6), $\mathrm{S} 22.8$ (22.4); IR $\left(v_{\max }, \mathrm{cm}^{-1}\right): 2048 v(\mathrm{CN}), 828 v(\mathrm{CS}), 483 \delta(\mathrm{NCS})$; UV/Vis $\left(\lambda_{\max }, \mathrm{nm} ; 23^{\circ} \mathrm{C}\right)$ : 535 (powder); 543 (acetone).

(BMIm) $\left[\mathbf{C r}(\mathbf{N C S})_{4}(\mathbf{P y r})_{2}\right]$ : Prepared from BMImCl [48] and $\mathrm{Ag}\left[\mathrm{Cr}(\mathrm{NCS})_{4}(\mathrm{Pyr})_{2}\right]$. Red hygroscopic solid, yield $71 \%$. M.p. $207^{\circ} \mathrm{C}$ (dec.); elemental analysis for $\mathrm{C}_{22} \mathrm{H}_{25} \mathrm{CrN}_{8} \mathrm{~S}_{4} \cdot 2 \mathrm{H}_{2} \mathrm{O}$ (calcd.): C 42.7 (42.8), H 4.7 (4.7), N 18.2 (18.1), S 21.0 (20.8); IR ( $\left.v_{\max }, \mathrm{cm}^{-1}\right)$ : 2055 v(CN), $829 v(\mathrm{CS}), 482 \delta(\mathrm{NCS}) ; \mathrm{UV} / \mathrm{Vis}\left(\lambda_{\max }, \mathrm{nm} ; 23^{\circ} \mathrm{C}\right): 535$ (powder); 543 (acetone).

(BenzMIm)[Cr(NCS) $\left.{ }_{4}(\mathbf{P y r})_{2}\right]$ : Prepared from BenzMImBr [47,54] and $\mathrm{Ag}\left[\mathrm{Cr}(\mathrm{NCS})_{4}(\mathrm{Pyr})_{2}\right]$. Red hygroscopic solid, yield $64 \%$. M.p. $185^{\circ} \mathrm{C}$ (dec.); elemental analysis for $\mathrm{C}_{25} \mathrm{H}_{23} \mathrm{CrN}_{8} \mathrm{~S}_{4} \cdot 2.5 \mathrm{H}_{2} \mathrm{O}$ (calcd.): C 45.4 (45.4), H 4.0 (4.3), N 15.8 (17.0), S 20.0 (19.4); IR ( $\left.v_{\max }, \mathrm{cm}^{-1}\right)$ : $2043 v(\mathrm{CN}), 820$ $v(\mathrm{CS}), 482 \delta(\mathrm{NCS})$; UV/Vis $\left(\lambda_{\max }, \mathrm{nm} ; 23^{\circ} \mathrm{C}\right): 535$ (powder); 543 (acetone).

PicH[Cr(NCS) $\left.)_{4}(\mathbf{P i c})_{2}\right]$ : Dried $\mathrm{K}_{3}\left[\mathrm{Cr}(\mathrm{NCS})_{6}\right](19.7 \mathrm{~g}, 38.0 \mathrm{mmol})$ was suspended in $\gamma$-picoline $(20.0 \mathrm{~g}, 214.8 \mathrm{mmol})$ and stirred for $4 \mathrm{~h}$ at $115^{\circ} \mathrm{C}$ in a sealed flask. After cooling to room temperature, the precipitate was washed with portions of acetic acid ( $10 \%$ aqueous solution, $100 \mathrm{~mL}$ ) and water. Afterward, the precipitate was dissolved in acetone/ethyl acetate $(v: v=1: 1,300 \mathrm{~mL})$ and the solution was combined with an aqueous $\mathrm{NH}_{4} \mathrm{Cl}$ solution ( $30 \mathrm{~g}$ in $150 \mathrm{~mL} \mathrm{H}_{2} \mathrm{O}$ ) and brought to reflux. The resulting solution was evaporated to dryness in vacuum and the precipitate was extracted with acetone. The combined 
acetonic solutions were evaporated to dryness in vacuum and the resulting red solid was finally dried for several hours in vacuum at $130{ }^{\circ} \mathrm{C}(18.4 \mathrm{~g}, 86 \%)$. Elemental analysis for $\mathrm{C}_{22} \mathrm{H}_{22} \mathrm{CrN}_{7} \mathrm{~S}_{4}$ (calcd). C 47.0 (46.8), H 4.2 (3.9), N 16.6 (17.4), S 27.9 (22.7). IR $\left(v_{\max }, \mathrm{cm}^{-1}\right)$ : $2043 v(\mathrm{CN}), 497 \delta(\mathrm{NCS})$.

$\mathbf{A g}\left[\mathbf{C r}(\mathrm{NCS})_{4}(\mathbf{P i c})_{2}\right]: \mathrm{PicH}\left[\mathrm{Cr}(\mathrm{NCS})_{4}(\mathrm{Pic})_{2}\right](5.0 \mathrm{~g}, 8.8 \mathrm{mmol})$ was dissolved in $100 \mathrm{~mL}$ acetone and slowly added to $100 \mathrm{~mL}$ of a vigorously stirred aqueous solution of $\mathrm{AgNO}_{3}$ ( $4.5 \mathrm{~g}, 26.5 \mathrm{mmol})$. The resulting precipitate was filtered off, washed with $\mathrm{H}_{2} \mathrm{O}, \mathrm{H}_{2} \mathrm{O}$ /acetone $(v: v=1: 1)$ and acetone, and finally dried in vacuum at room temperature for several hours, yielding a reddish solid (4.7 g, 92\%). Elemental analysis for $\mathrm{C}_{16} \mathrm{H}_{14} \mathrm{AgCrN}_{6} \mathrm{~S}_{4}$ (calcd). C 30.2 (33.2), H 2.1 (2.4), N 13.4 (14.5), S 22.2 (22.2). IR ( $\left.v_{\max }, \mathrm{cm}^{-1}\right)$ : $2049 v(\mathrm{CN}), 497 \delta(\mathrm{NCS})$.

(DMIm) $\left[\mathrm{Cr}(\mathrm{NCS})_{4}(\mathrm{Pic})_{2}\right]$ : Prepared from DMImI [51] and $\mathrm{Ag}\left[\mathrm{Cr}(\mathrm{NCS})_{4}(\mathrm{Pic})_{2}\right]$. Red solid, yield $80 \%$. M.p. $>220{ }^{\circ} \mathrm{C}$ (dec.); elemental analysis for $\mathrm{C}_{21} \mathrm{H}_{23} \mathrm{CrN}_{8} \mathrm{~S}_{4}$. acetone (calcd.): C 46.3 (46.1), H 4.3 (4.7), N 17.5 (17.9), S 20.6 (20.5); IR $\left(v_{\max }, \mathrm{cm}^{-1}\right)$ : $2052 v(\mathrm{CN})$, $813 v(\mathrm{CS}), 497 \delta(\mathrm{NCS}) ; \mathrm{UV} / \mathrm{Vis}\left(\lambda_{\max }, \mathrm{nm} ; 23^{\circ} \mathrm{C}\right): 537$ (powder); 541 (acetone).

(EMIm) $\left[\mathrm{Cr}(\mathrm{NCS})_{4}(\mathbf{P i c})_{2}\right.$ ]: Prepared from EMImBr [49] and $\mathrm{Ag}\left[\mathrm{Cr}(\mathrm{NCS})_{4}(\mathrm{Pic})_{2}\right]$. Red solid, yield $96 \%$. M.p. $194{ }^{\circ} \mathrm{C}$ (dec.); elemental analysis for $\mathrm{C}_{22} \mathrm{H}_{25} \mathrm{CrN}_{8} \mathrm{~S}_{4}$ (calcd.): $\mathrm{C} 45.6$ (45.4), H 4.1 (4.3), N 16.5 (19.3), S 21.9 (22.1); IR $\left(v_{\max }, \mathrm{cm}^{-1}\right)$ : $2050 v(\mathrm{CN}), 813 v(\mathrm{CS}), 497$ $\delta$ (NCS); UV/Vis $\left(\lambda_{\max }, \mathrm{nm} ; 2{ }^{\circ} \mathrm{C}\right): 537$ (powder); 541 (acetone).

(BMIm) $\left[\mathbf{C r}(\mathbf{N C S})_{4}\left(\mathbf{P i c}_{2}\right]\right.$ : Prepared from BMImCl [48] and $\mathrm{Ag}\left[\mathrm{Cr}(\mathrm{NCS})_{4}(\mathrm{Pic})_{2}\right]$. Red solid, yield $76 \%$. M.p. $191{ }^{\circ} \mathrm{C}$ (dec.); elemental analysis for $\mathrm{C}_{24} \mathrm{H}_{29} \mathrm{CrN}_{8} \mathrm{~S}_{4} \cdot \mathrm{H}_{2} \mathrm{O}$ (calcd.): $\mathrm{C}$ 46.4 (45.9), H 4.7 (5.0), N 16.0 (17.9), S 20.0 (20.4); IR ( $\left.v_{\max }, \mathrm{cm}^{-1}\right)$ : 2032 v(CN), 812 v(CS), $497 \delta(\mathrm{NCS}) ; \mathrm{UV} / \mathrm{Vis}\left(\lambda_{\max }, \mathrm{nm} ; 23^{\circ} \mathrm{C}\right): 537$ (powder); 541 (acetone).

(BenzMIm) [Cr(NCS $)_{4}(\text { Pic })_{2}$ ]: Prepared from BenzMImBr [47,54] and $\mathrm{Ag}\left[\mathrm{Cr}(\mathrm{NCS})_{4}(\mathrm{Pic})_{2}\right]$. Red solid, yield $61 \%$. M.p. $195{ }^{\circ} \mathrm{C}$ (dec.); elemental analysis for $\mathrm{C}_{27} \mathrm{H}_{27} \mathrm{CrN}_{8} \mathrm{~S}_{4} \cdot 0.5 \mathrm{H}_{2} \mathrm{O}$ (calcd.): C 49.6 (49.7), H 4.5 (4.3), N 15.7 (17.2), S 19.0 (19.6); IR $\left(v_{\max }, \mathrm{cm}^{-1}\right)$ : $2034 \gamma(\mathrm{CN})$, $811 v(\mathrm{CS}), 497 \delta(\mathrm{NCS}) ; \mathrm{UV} /$ Vis $\left(\lambda_{\max }, \mathrm{nm} ; 23^{\circ} \mathrm{C}\right): 537$ (powder); 541 (acetone).

\section{Results}

\subsection{Syntheses}

The two different routes to generate homoleptic imidazolium-based $\mathrm{Cr}$ III complexes of the general formula $(R \mathrm{MIm})_{3}\left[\mathrm{Cr}(\mathrm{NCS})_{6}\right](R=$ methyl, ethyl, n-butyl, benzyl) are depicted in Scheme 1. The synthetic approach can be divided into two different routes: (I) the rapid, non-organic solvent, aqueous solution-based salt metathesis of ionic liquid precursors $(R \mathrm{MIm}) X(R=$ methyl, ethyl, n-butyl, benzyl; $X=\mathrm{Cl}, \mathrm{Br}, \mathrm{I})$ and $\mathrm{K}_{3}\left[\mathrm{Cr}(\mathrm{NCS})_{6}\right]$, or (II) the one-pot, direct reaction of ionic liquid precursors (RMIm)X with $\mathrm{CrCl}_{3}$ and $\mathrm{KSCN}$ in acetonic solution. Both routes lead to the same low-melting $\mathrm{Cr}$ (III)-based ionic liquid $(R M I m)_{3}\left[\mathrm{Cr}(\mathrm{NCS})_{6}\right]$ materials with high yields. The overall yield of route I is slightly below the overall yield of route II, mainly because of the work-up strategy. Starting in route II with $\mathrm{CrCl}_{3}$ and using an organic solvent makes the product separation more effective than in the aqueous strategy used in route I. 


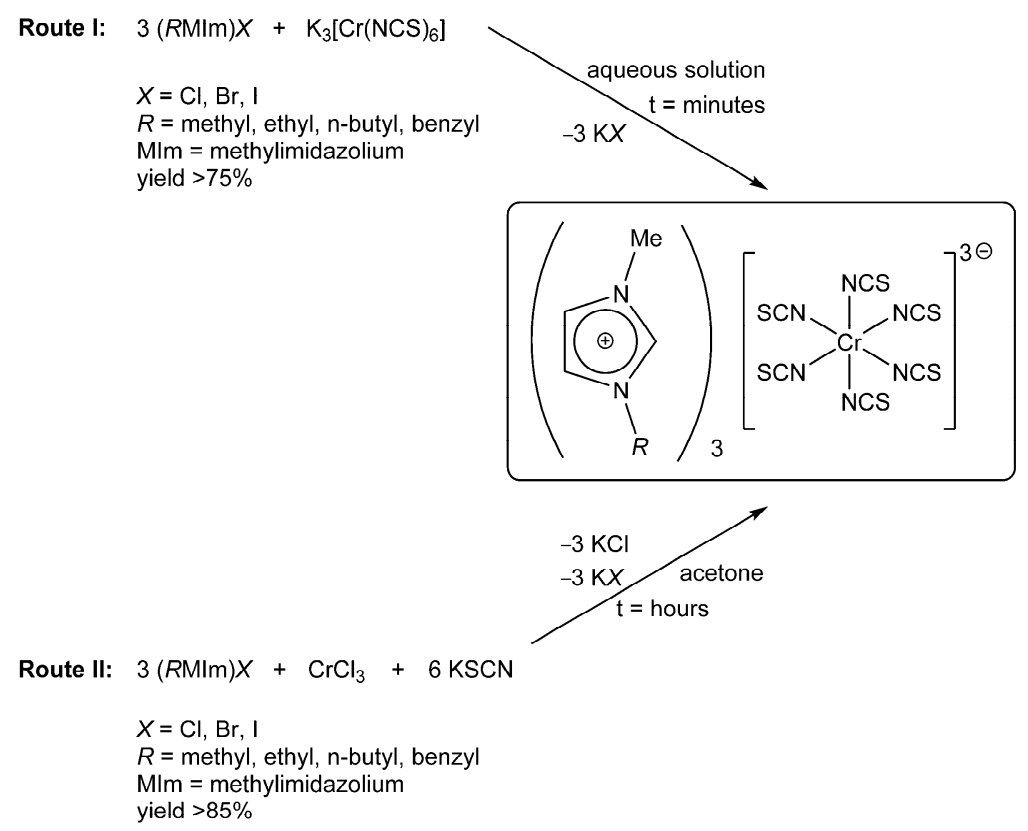

Scheme 1. The two general synthetic approaches for the syntheses of complexes of the general formula $(R \mathrm{MIm})_{3}\left[\mathrm{Cr}(\mathrm{NCS})_{6}\right](R=$ methyl, ethyl, n-butyl, benzyl; MIm = methylimidazolium).

The route for the heteroleptic complexes of the formula $(R \mathrm{MIm})\left[\mathrm{Cr}(\mathrm{NCS})_{4} L_{2}\right](R=$ ethyl, n-butyl; MIm $=N$-methylimidazolium; $L=$ pyridine, $\gamma$-picoline) is given in Scheme 2 . The general synthetic procedure includes a three-step reaction pathway starting from $\mathrm{K}_{3}\left[\mathrm{Cr}(\mathrm{NCS})_{6}\right]$. In a first step, $\mathrm{K}_{3}\left[\mathrm{Cr}(\mathrm{NCS})_{6}\right]$ is reacted with and in excess $L(L=$ pyr, pic), afterward the $L \mathrm{H}\left[\mathrm{Cr}(\mathrm{NCS})_{4} L_{2}\right]$ compound is further transferred into its $\mathrm{Ag}$ salt. A subsequent salt metathesis reaction with ionic liquid precursors $(R M I m) X$ leads to the final products $(R M I m)\left[\mathrm{Cr}(\mathrm{NCS})_{4} L_{2}\right]$ in moderate yields.
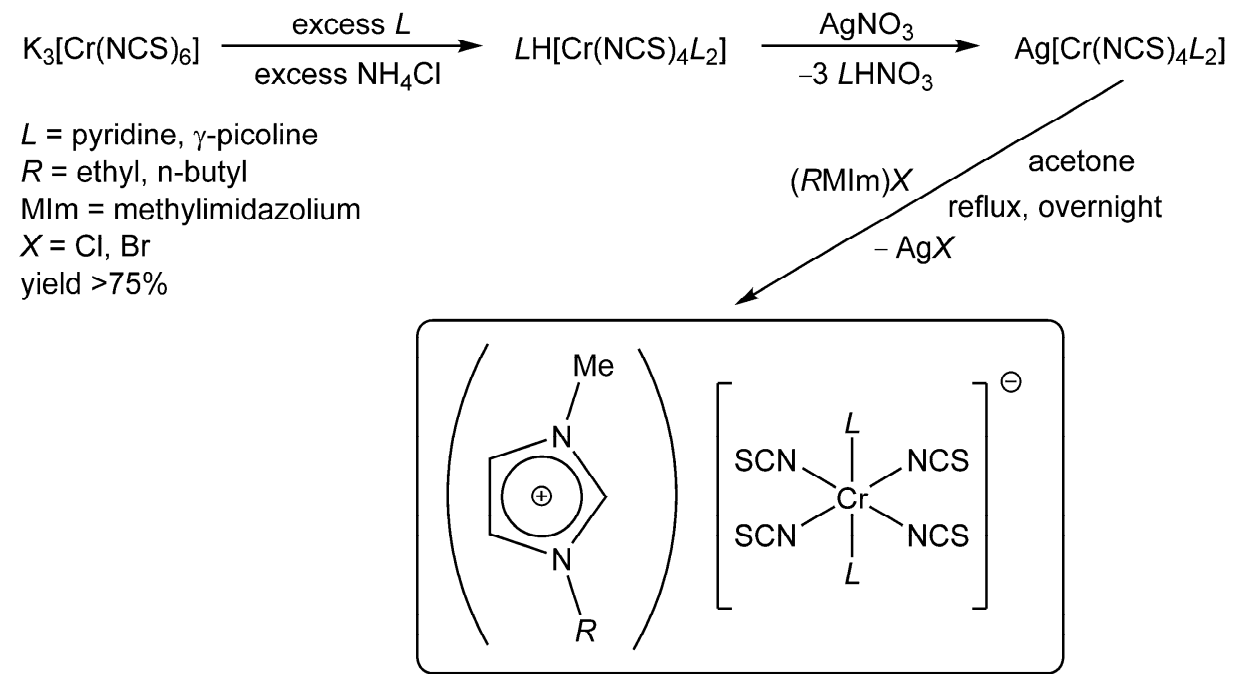

Scheme 2. Multi-step synthetic approach to generate complexes with the general formula $(R \mathrm{MIm})\left[\mathrm{Cr}(\mathrm{NCS})_{4} L_{2}\right](R=$ ethyl, $\mathrm{n}$-butyl; MIm $=N$-methylimidazolium; $L=$ pyridine, $\gamma$-picoline $)$.

\subsection{Physicochemical Properties: Electronic and Infrared Data}

Octahedral $\mathrm{Cr}^{\mathrm{III}}$ complexes exhibit two distinct spin allowed transitions in the visible region, namely ${ }^{4} \mathrm{~T}_{2 \mathrm{~g}} \leftarrow{ }^{4} \mathrm{~A}_{2 \mathrm{~g}}$ (low energy) and ${ }^{4} \mathrm{~T}_{1 \mathrm{~g}}(\mathrm{~F}) \leftarrow{ }^{4} \mathrm{~A}_{2 \mathrm{~g}}$ (higher energy). An additional third short-wave band, ${ }^{4} \mathrm{~T}_{1 g}(\mathrm{P}) \leftarrow{ }^{4} \mathrm{~A}_{2 \mathrm{~g}}$ (highest energy), is usually superimposed by charge-transfer bands [57]. Electronic spectra for complexes bearing the $\left[\mathrm{Cr}(\mathrm{NCS})_{4} L_{2}\right]^{-}$ ( $L=$ eg. $\mathrm{NH}_{3}$, amines, phosphines) anion are reported in the literature in detail. For 
$\mathrm{N}$-donor ligands, the spectrochemical series is reported to be $\mathrm{NCS}^{-}<\mathrm{Pyr}<\mathrm{NH}_{3}$ [58]. For Reineckates $\left(L=\mathrm{NH}_{3}\right)$, transitions are reported at 392 and $503 \mathrm{~nm}$, and for $L=P y r$ at $545 \mathrm{~nm}$, respectively, in the solid state under diffuse reflectance conditions [58].

$\mathrm{UV} /$ Vis spectra in diffuse reflectance as well as in an acetonic solution of selected $(\mathrm{EMIm})_{\mathrm{x}}\left[\mathrm{Cr}(\mathrm{NCS})_{4} L_{2}\right](\mathrm{x}=3: L=\mathrm{NCS} ; \mathrm{x}=1: L=\mathrm{Pyr}, \mathrm{Pic})$ compounds are depicted in Figure 1. Full information on all transitions are given in the Experimental section and maxima for compounds exhibiting the $\left[\mathrm{Cr}(\mathrm{NCS})_{6}\right]^{-}$anion are found at 413 (416) and 552 (556) nm, for $L=$ Pyr at 535 (543) nm, and for $L=$ Pic at 537 (541) nm, respectively. These values closely resemble the ones found in the literature and the ligand field strength is also in accordance $[31-33,56,58]$.

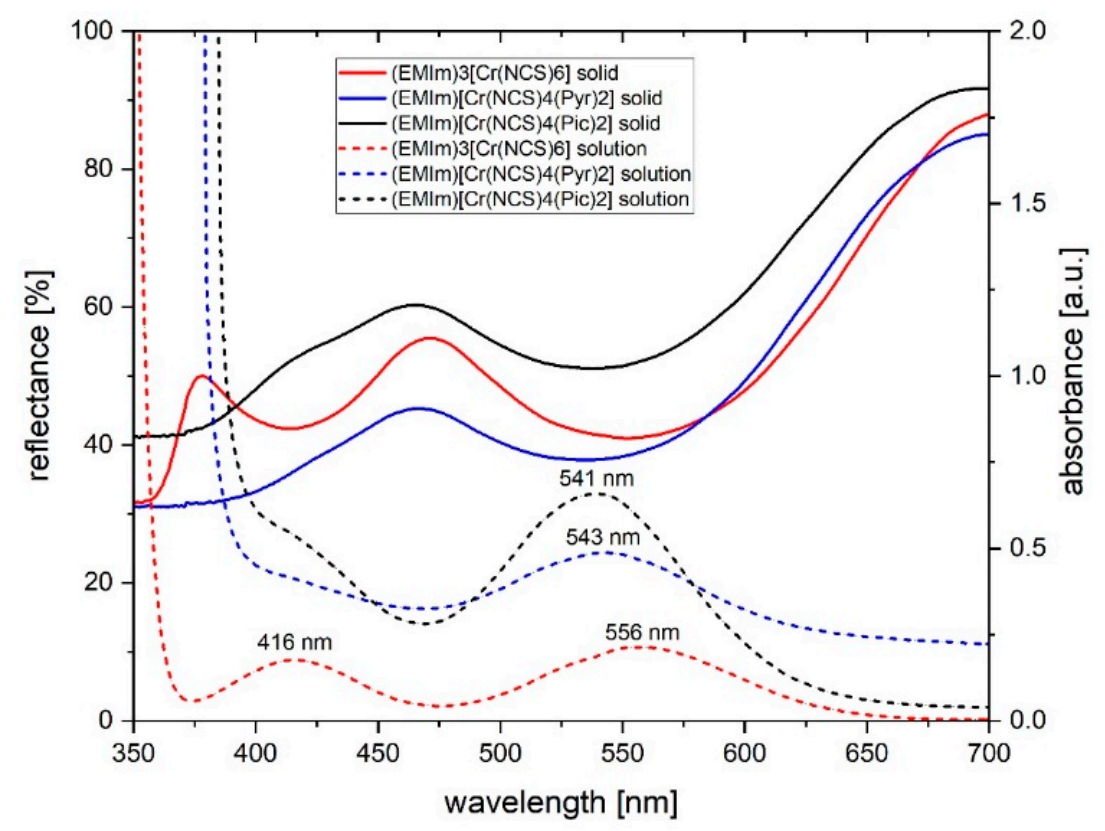

Figure 1. UV/Vis spectra of solid samples (solid lines) and acetonic solutions (dashed lines) of samples of $(\mathrm{EMIm})_{\mathrm{x}}\left[\mathrm{Cr}(\mathrm{NCS})_{4} L_{2}\right](\mathrm{x}=3: L=\mathrm{NCS} ; \mathrm{x}=1: L=$ Pyr, Pic).

\subsection{Thermal Properties}

All substances were subjected to thermogravimetric analyses (TGA) and differential scanning calorimetry (DSC) measurements to investigate their thermal as well as melting behavior. The melting points were detected as endothermic peaks in the DSC measurements and are listed in the Experimental section and in Table 1.

Table 1. Melting points $\left[{ }^{\circ} \mathrm{C}\right]$ derived from the DSC measurements of substances of the general formula $(R \mathrm{MIm})_{3}\left[\mathrm{Cr}(\mathrm{NCS})_{6}\right]$ and $(R \mathrm{MIm})\left[\mathrm{Cr}(\mathrm{NCS})_{4} L_{2}\right](R=$ Methyl, Ethyl, Benzyl; $L=$ Pyr, Pic; dec.: with decomposition).

\begin{tabular}{|c|c|c|c|}
\hline$R$ & $(R \mathrm{MIm})_{3}\left[\mathrm{Cr}(\mathrm{NCS})_{6}\right]$ & $(\mathrm{RMIm})\left[\mathrm{Cr}(\mathrm{NCS})_{4}(\mathrm{Pyr})_{2}\right]$ & $(\mathrm{RMIm})\left[\mathrm{Cr}(\mathrm{NCS})_{4}(\mathrm{Pic})_{2}\right]$ \\
\hline Methyl & 138 & 180 (dec.) & 220 (dec.) \\
\hline Ethyl & 84 & 191 (dec.) & 194 (dec.) \\
\hline n-Butyl & 45 & 207 (dec.) & 191 (dec.) \\
\hline Benzyl & 124 & 185 (dec.) & 195 (dec.) \\
\hline
\end{tabular}

Compounds of the formula $(R \mathrm{MIm})_{3}\left[\mathrm{Cr}(\mathrm{NCS})_{6}\right](R=$ methyl, ethyl, n-butyl, benzyl) can be melted and recrystallized without decomposition, whereas the comparable compounds with pyridine or picoline ligands melt with decomposition. The melting points of the hexaisothiocyanato complexes can be lowered by extending the alkyl chain in the imidazolium-based cation from $138{ }^{\circ} \mathrm{C}$ in (DMIm) $)_{3}\left[\mathrm{Cr}(\mathrm{NCS})_{6}\right]$ to $45^{\circ} \mathrm{C}$ in $(\mathrm{BMIm})_{3}\left[\mathrm{Cr}(\mathrm{NCS})_{6}\right]$. This behavior can be found in a variety of other ionic liquids and 
ionic liquid complexes, but these melting points are exceptionally low for triply charged $\mathrm{Cr}$ (III)-based compounds. A recent study has shown that low charge density can be attributed to the low melting points of systems with high charges [59]. Hence, this behavior could be present, particularly in systems also exhibiting the symmetric $\left[\mathrm{Cr}(\mathrm{NCS})_{6}\right]^{3-}$ complex anion, leading to the observed low melting points. In contrast, the melting points were not as low as for the comparable doubly charged complexes (e.g., the low-viscosity isothiocyanato-based compound [EMIm $\left.]_{2}\left[\mathrm{Co}(\mathrm{NCS})_{4}\right]\right)[26]$.

Decomposition curves of the three selected substances $(\mathrm{EMIm})_{\mathrm{x}}\left[\mathrm{Cr}(\mathrm{NCS})_{4} L_{2}\right](\mathrm{x}=3$ : $L=$ NCS; $\mathrm{x}=1: L=\mathrm{Pyr}, \mathrm{Pic}$ ) in a nitrogen atmosphere in the temperature range 25 to $400{ }^{\circ} \mathrm{C}$ are shown in Figure 2. From Figure 2, it can be seen that the decomposition of $(\mathrm{EMIm})_{3}\left[\mathrm{Cr}(\mathrm{NCS})_{6}\right]$ starts at ca. $300{ }^{\circ} \mathrm{C}$ and the compounds stay undecomposed in the liquid state of a range of more than $200 \mathrm{~K}$. Compounds (EMIm) $\left[\mathrm{Cr}(\mathrm{NCS})_{4} L_{2}\right](L=\mathrm{Pyr}$, Pic) melt just below $200{ }^{\circ} \mathrm{C}$ by loss of ca. $5 \%$ mass. This can be attributed to the beginning release and evaporation of pyridine or picoline ligands into the gas phase. The gradual decomposition is further accelerated above $300{ }^{\circ} \mathrm{C}$, which is comparable to the behavior of $(\mathrm{EMIm})_{3}\left[\mathrm{Cr}(\mathrm{NCS})_{6}\right]$ and comparable amine-based isothiocyanate chromate(III) complexes [56].

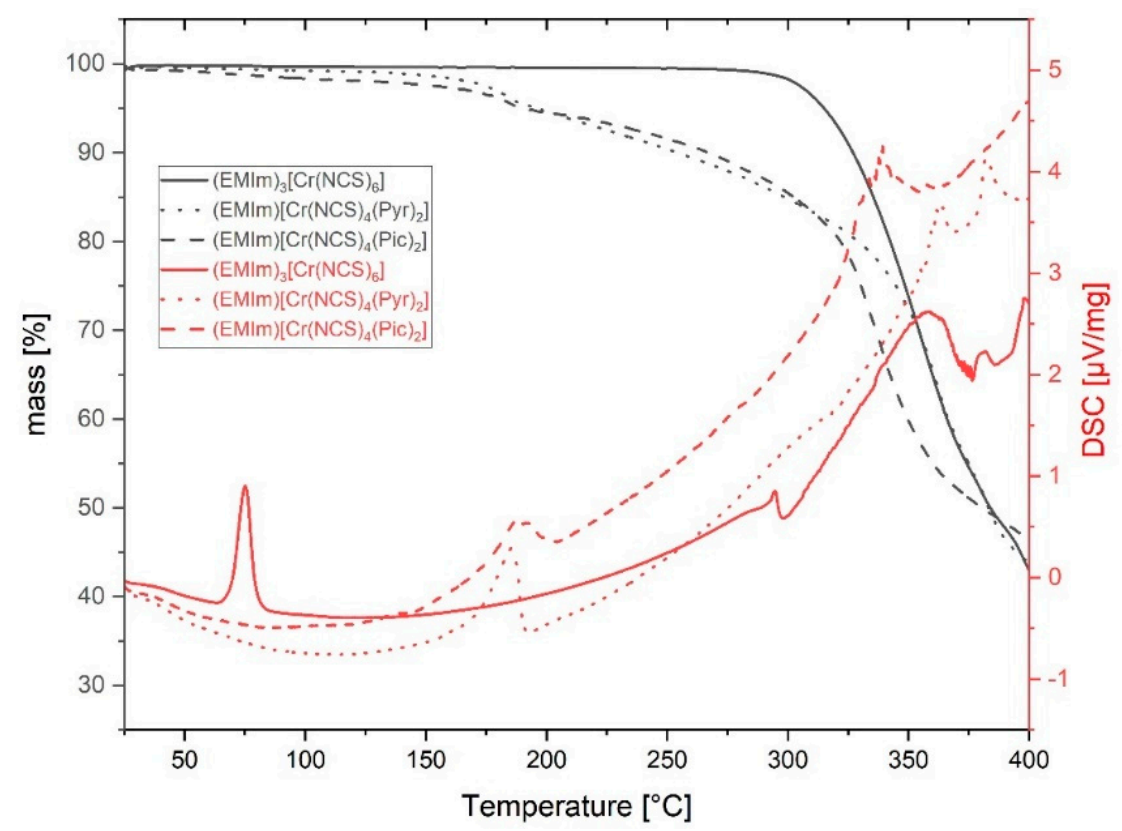

Figure 2. Thermogravimetric (black) and DSC (red) results of samples of (EMIm) $)_{x}\left[\mathrm{Cr}(\mathrm{NCS})_{4} L_{2}\right]$ ( $\mathrm{x}=3: L=\mathrm{NCS} ; \mathrm{x}=1: L=\mathrm{Pyr}, \mathrm{Pic})$ in a $\mathrm{N}_{2}$ atmosphere.

\subsection{Crystal Structures}

Single crystals suitable for X-ray structure determinations of $(R \mathrm{MIm})_{3}\left[\mathrm{Cr}(\mathrm{NCS})_{6}\right]$ $\left(R\right.$ = methyl, ethyl, benzyl), (BMIm) $\left[\mathrm{Cr}(\mathrm{NCS})_{4}(\mathrm{Pyr})_{2}\right]$, and $(\mathrm{EMIm})\left[\mathrm{Cr}(\mathrm{NCS})_{4}(\mathrm{Pic})_{2}\right]$ were obtained by slow evaporation acetonic solutions of the three compounds at ambient pressure and temperatures of $25^{\circ} \mathrm{C}$ over a period of one week. Crystallographic data and structure-refinement parameters of all five compounds can be found in Table 2. Additional selected interatomic distances for the complex anions and hydrogen-bond geometries are given in Table 3. 
Table 2. Crystallographic data and structure-refinement parameters for $(R M I m)_{3}\left[\mathrm{Cr}(\mathrm{NCS})_{6}\right](R=\operatorname{Methyl}, \mathrm{Ethyl}, \mathrm{Benzyl}),(\mathrm{BMIm})\left[\mathrm{Cr}(\mathrm{NCS})_{4}(\mathrm{Pyr})_{2}\right]$, and $(\mathrm{EMIm})\left[\mathrm{Cr}(\mathrm{NCS})_{4}(\mathrm{Pic})_{2}\right]$.

\begin{tabular}{|c|c|c|c|c|c|}
\hline & $(\mathrm{DMIm})_{3}\left[\mathrm{Cr}(\mathrm{NCS})_{6}\right]$ & $(\mathrm{EMIm})_{3}\left[\mathrm{Cr}(\mathrm{NCS})_{6}\right]$ & $(\text { BenzMIm })_{3}\left[\mathrm{Cr}(\mathrm{NCS})_{6}\right]$ & $(\mathrm{BMIm})\left[\mathrm{Cr}(\mathrm{NCS})_{4}(\mathrm{Pyr})_{2}\right]$ & $(\mathrm{EMIm})\left[\mathrm{Cr}(\mathrm{NCS})_{4}(\mathrm{Pic})_{2}\right]$ \\
\hline Formula & $\mathrm{C}_{21} \mathrm{H}_{27} \mathrm{CrN}_{12} \mathrm{~S}_{6}$ & $\mathrm{C}_{24} \mathrm{H}_{33} \mathrm{CrN}_{12} \mathrm{~S}_{6}$ & $\mathrm{C}_{39} \mathrm{H}_{39} \mathrm{CrN}_{12} \mathrm{~S}_{6}$ & $\mathrm{C}_{22} \mathrm{H}_{25} \mathrm{CrN}_{8} \mathrm{~S}_{4}$ & $\mathrm{C}_{22} \mathrm{H}_{25} \mathrm{CrN}_{8} \mathrm{~S}_{4}$ \\
\hline $\mathrm{Fw}\left[\mathrm{g} \mathrm{mol}^{-1}\right]$ & 691.90 & 733.98 & 920.18 & 581.74 & 581.74 \\
\hline Crystal system & triclinic & trigonal & monoclinic & triclinic & orthorhombic \\
\hline$a[\AA]$ & $9.4116(6)$ & $18.220(3)$ & $18.6109(8)$ & $8.3939(5)$ & $17.1199(9)$ \\
\hline$b[\AA]$ & $10.0862(6)$ & $19.198(4)$ & $13.4405(6)$ & $9.9145(6)$ & $15.5043(8)$ \\
\hline$c[\AA]$ & $18.630(1)$ & $18.220(3)$ & $17.9848(8)$ & $17.447(1)$ & $20.981(1)$ \\
\hline$\left.\alpha^{2}{ }^{\circ}\right]$ & $87.525(4)$ & 90.0 & 90.0 & $101.441(2)$ & 90.0 \\
\hline$\beta\left[^{\circ}\right]$ & $81.527(3)$ & 90.0 & $97.967(2)$ & $91.854(3)$ & 90.0 \\
\hline$\gamma[0]$ & $75.893(3)$ & 120.0 & 90.0 & $97.682(2)$ & 90.0 \\
\hline$V\left[\AA^{3}\right], Z$ & $1696.4(2), 2$ & $5519(2), 6$ & $4455.3(3), 4$ & $1407.7(1), 2$ & $5569.0(6), 8$ \\
\hline$T[\mathrm{~K}]$ & 293 & 293 & 173 & 173 & 173 \\
\hline$\rho_{\text {calcd. }}\left[\mathrm{g} \mathrm{cm}^{-3}\right]$ & 1.355 & 1.325 & 1.372 & 1.372 & 1.388 \\
\hline$\mu\left[\mathrm{mm}^{-1}\right]$ & 0.73 & 0.679 & 0.576 & 0.724 & 0.732 \\
\hline Reflections collected & 34,948 & 46,540 & 37,816 & 22,262 & 24,664 \\
\hline Independent reflections & 11,424 & 4056 & 9172 & 6917 & 6939 \\
\hline Parameters & 364 & 179 & 526 & 347 & 373 \\
\hline GooF & 1.00 & 1.02 & 0.96 & 1.02 & 0.99 \\
\hline$R\left[F^{2}>2 \sigma\left(F^{2}\right)\right]$ & 0.047 & 0.042 & 0.056 & 0.045 & 0.047 \\
\hline$w R\left(F^{2}\right)^{(a, b)}$ & 0.153 & 0.140 & 0.114 & 0.122 & 0.133 \\
\hline
\end{tabular}

(a) $R 1=\frac{\sum|| F_{0}|-| F_{c}||}{\sum\left|F_{0}\right|} ; \mathrm{wR} 2=\sqrt{\frac{\sum w\left(F_{o}^{2}-F_{c}^{2}\right)^{2}}{\sum w\left(F_{0}^{2}\right)^{2}}} ;(b) w=1 /\left[\left(\sigma^{2}\left(F_{o}^{2}\right)+(A * P)^{2}+B * P\right] ; P=\frac{F_{0}^{2}+2 F_{c}^{2}}{3}\right.$.

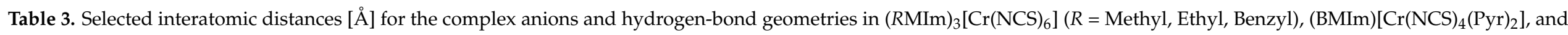
$(\mathrm{EMIm})\left[\mathrm{Cr}(\mathrm{NCS})_{4}(\mathrm{Pic})_{2}\right]$.

\begin{tabular}{|c|c|c|c|c|c|}
\hline Bond & $(\mathrm{DMIm})_{3}\left[\mathrm{Cr}(\mathrm{NCS})_{6}\right]$ & $(\mathrm{EMIm})_{3}\left[\mathrm{Cr}(\mathrm{NCS})_{6}\right]$ & $\left({\text { BenzMIm })_{3}\left[\mathrm{Cr}(\mathrm{NCS})_{6}\right]}\right.$ & $(\mathrm{BMIm})\left[\mathrm{Cr}(\mathrm{NCS})_{4}(\mathrm{Pyr})_{2}\right]$ & $(\mathrm{EMIm})\left[\mathrm{Cr}(\mathrm{NCS})_{4}(\mathrm{Pic})_{2}\right]$ \\
\hline average $\mathrm{Cr}-\mathrm{N}$ & 2.01 & 2.00 & 2.00 & $1.99 / 2.08(\mathrm{Cr}-L)$ & $1.99 / 2.08(\mathrm{Cr}-L)$ \\
\hline average $\mathrm{N}-\mathrm{C}$ & 1.14 & 1.14 & 1.16 & 1.16 & 1.16 \\
\hline average C-S & 1.62 & 1.62 & 1.63 & 1.62 & 1.62 \\
\hline $\begin{array}{l}\text { short. } D-H \cdots A \\
\text { C-H }\end{array}$ & 093 & & & & \\
\hline H...S & $\begin{array}{l}0.93 \\
2.72\end{array}$ & $\begin{array}{l}0.93 \\
2.99\end{array}$ & 0.99 & 0.95 & 0.95 \\
\hline C $\cdots S$ & $3.620(2)$ & $3682(8)$ & 2.86 & 2.77 & 2.95 \\
\hline $\mathrm{C}-\mathrm{H} \cdots \mathrm{S}\left[^{\circ}\right]$ & $\begin{array}{c}3.020(2) \\
164\end{array}$ & $\begin{array}{l}3.682(0) \\
133\end{array}$ & $\begin{array}{l}3.3 / 0(4) \\
129\end{array}$ & $3.647(3)$ & $3.661(3)$ \\
\hline
\end{tabular}


Crystal structure determinations of ammonium-based $\left[\mathrm{Cr}(\mathrm{NCS})_{6}\right]^{3-}$ compounds have so far only been known for the two compounds $\left(\mathrm{NH}_{4}\right)_{3}\left[\mathrm{Cr}(\mathrm{NCS})_{6}\right] \cdot$ acetone and $\left(\mathrm{Me}_{4} \mathrm{~N}\right)_{3}\left[\mathrm{Cr}(\mathrm{NCS})_{6}\right]$ [60]. The crystal structure of an additional phosphonium-based compound is known for $\left(\mathrm{Ph}_{4} \mathrm{P}\right)_{3}\left[\mathrm{Cr}(\mathrm{NCS})_{6}\right]$-acetonitrile [61]. All these salts exhibit high melting points far beyond $100^{\circ} \mathrm{C}$, hence the crystal structure determinations of the new low-melting salts can provide a high impact to the structural information database.

Thermal ellipsoid plots of the structural units in (DMIm) ${ }_{3}\left[\mathrm{Cr}(\mathrm{NCS})_{6}\right],(\mathrm{BMIm})\left[\mathrm{Cr}(\mathrm{NCS})_{4}\right.$ $\left.(\mathrm{Pyr})_{2}\right],(\mathrm{EMIm})\left[\mathrm{Cr}(\mathrm{NCS})_{4}(\mathrm{Pic})_{2}\right],(\mathrm{EMIm})_{3}\left[\mathrm{Cr}(\mathrm{NCS})_{6}\right]$, and $(\text { BenzMIm })_{3}\left[\mathrm{Cr}(\mathrm{NCS})_{6}\right]$ are given in Figures 3-7, respectively. Figures 3, 4, 6 and 7 also depict the shortest hydrogen contacts $(\mathrm{C}-\mathrm{H} \cdots \mathrm{S})$ between the isothiocyanato ligands of the complex anions and the hydrogen atoms of the cations. Except for these shortest hydrogen contacts between cations and anions, additional hydrogen anion-anion interactions seem to be present in the molecular structure of (EMIm) $\left[\mathrm{Cr}(\mathrm{NCS})_{4}(\mathrm{Pic})_{2}\right]$ (Figure 5). This behavior has not yet been reported in comparable molecular structures of Reineckate-related compounds in the literature.

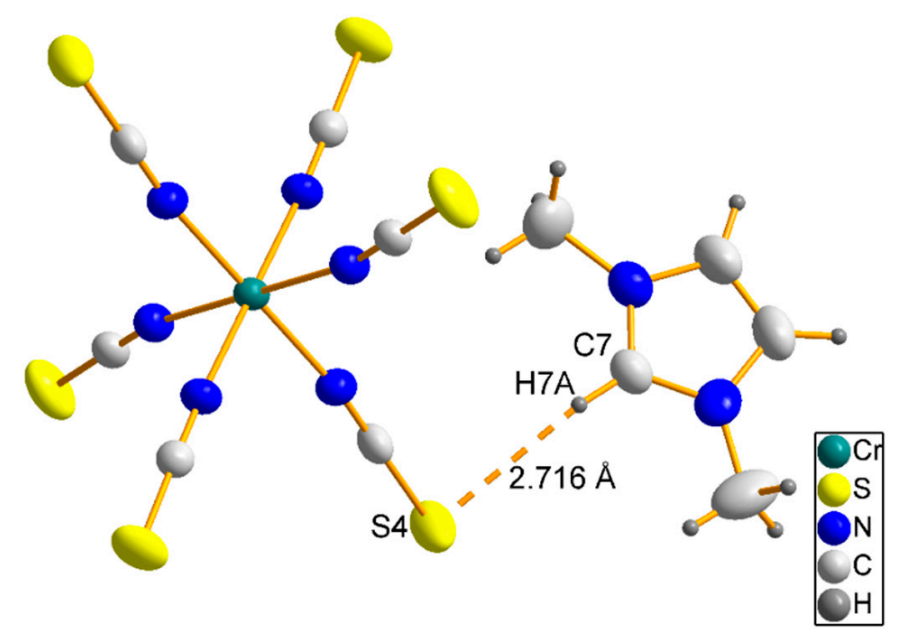

Figure 3. Structure of the cation-anion pair in (DMIm) $)_{3}\left[\mathrm{Cr}(\mathrm{NCS})_{6}\right]$ with atom labeling scheme depicting the shortest $\mathrm{C}-\mathrm{H} \cdots \mathrm{S}$ contact (thermal ellipsoids are drawn at the $30 \%$ probability level).

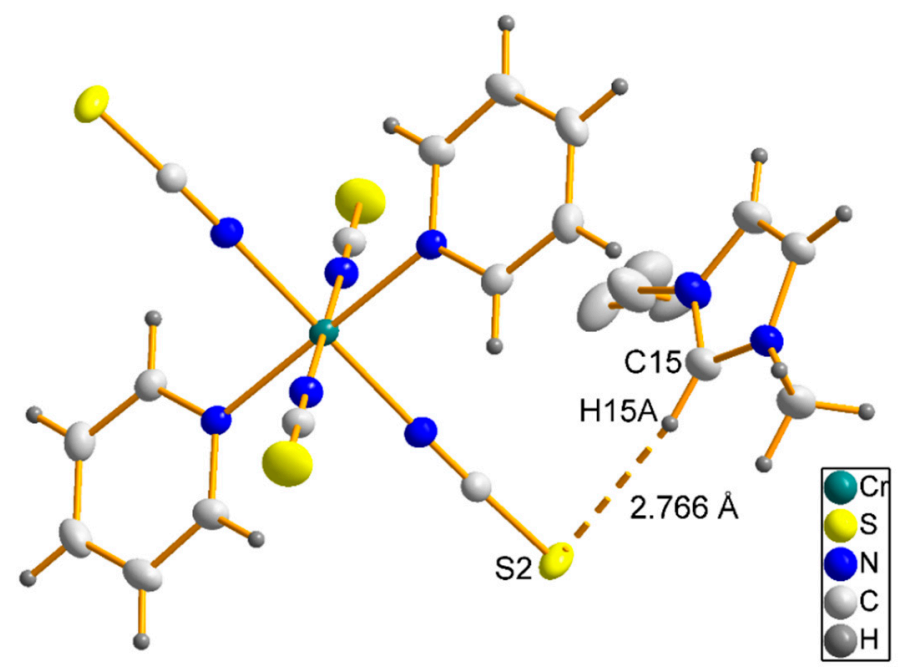

Figure 4. Structure of the cation-anion pair in (BMIm) $\left[\mathrm{Cr}(\mathrm{NCS})_{4}(\mathrm{Pyr})_{2}\right]$ with atom labeling scheme depicting the shortest $\mathrm{C}-\mathrm{H} \cdots \mathrm{S}$ contact (thermal ellipsoids are drawn at the $30 \%$ probability level; hydrogen atoms at the disordered n-butyl chain omitted for clarity). 


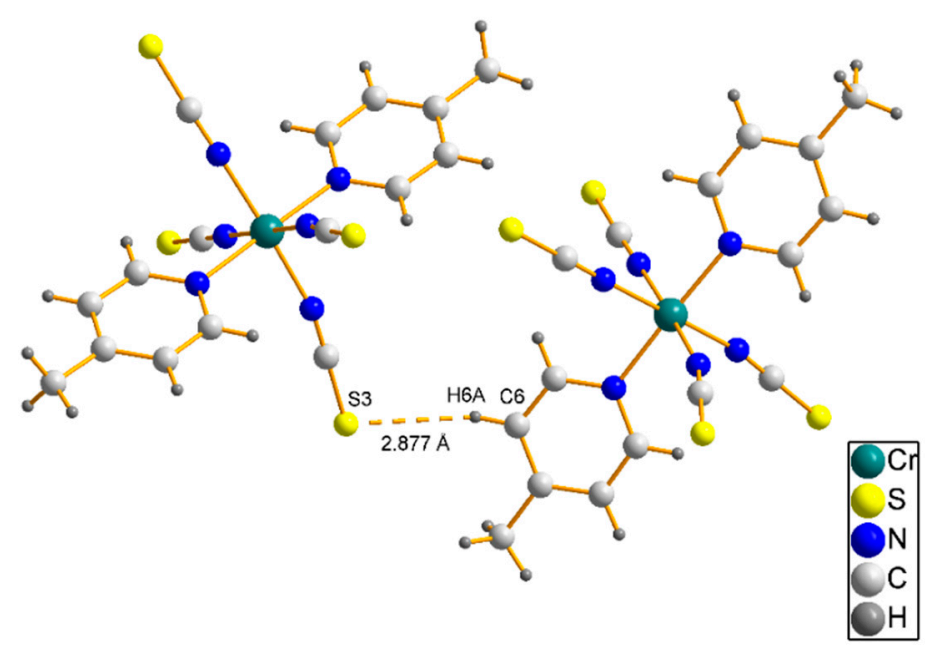

Figure 5. Anion-anion pairing in (EMIm) $\left[\mathrm{Cr}(\mathrm{NCS})_{4}(\mathrm{Pic})_{2}\right]$ via short hydrogen contacts with atom labeling scheme depicting the shortest C-H...S contact (thermal ellipsoids are drawn at the $30 \%$ probability level; disordered cation omitted for clarity).

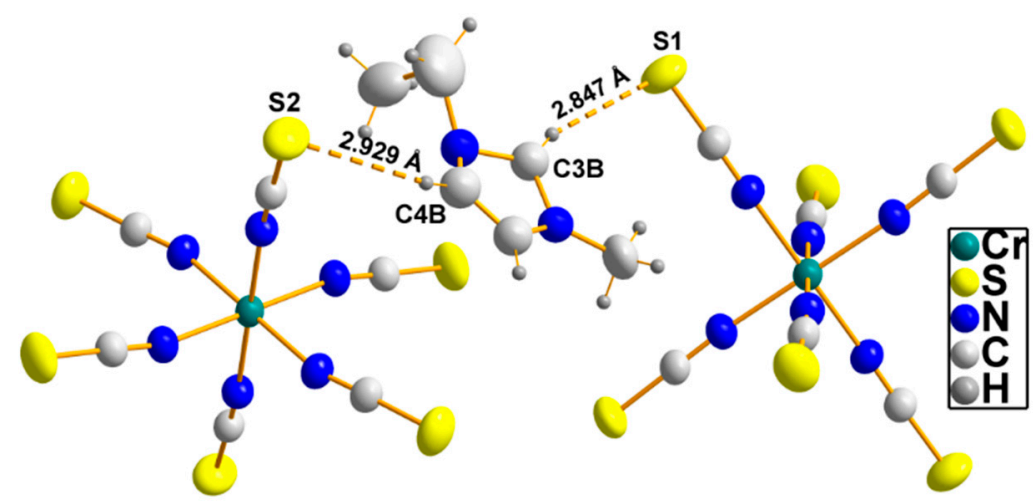

Figure 6. Anion-cation pairing in $(\mathrm{EMIm})_{3}\left[\mathrm{Cr}(\mathrm{NCS})_{6}\right]$ via short hydrogen contacts depicting the shortest $\mathrm{C}-\mathrm{H} \cdots \mathrm{S}$ contact (thermal ellipsoids are drawn at the $30 \%$ probability level).

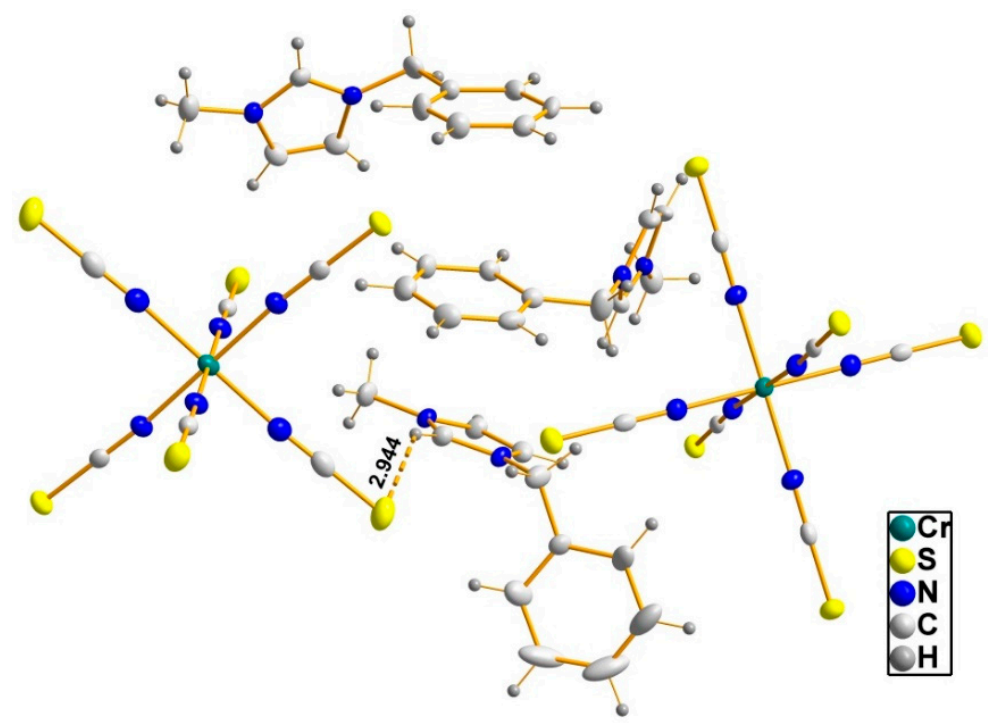

Figure 7. Anion-cation pairing in (BenzMIm) $)_{3}\left[\mathrm{Cr}(\mathrm{NCS})_{6}\right]$ via short hydrogen contacts depicting the shortest $\mathrm{C}-\mathrm{H} \cdots \mathrm{S}$ contact (thermal ellipsoids are drawn at the $30 \%$ probability level).

In all five structurally characterized compounds, the complex anions $\left[\mathrm{Cr}(\mathrm{NCS})_{6}\right]^{3-}$ and $\left[\mathrm{Cr}(\mathrm{NCS})_{4}(L)_{2}\right]^{-}(L=\mathrm{Pyr}, \mathrm{Pic})$ consist of $\mathrm{Cr}^{\mathrm{III}}$ ions coordinated octahedrally by either 
six isothiocyanato ligands with average $\mathrm{Cr}-\mathrm{N}$ bond lengths of 2.00-2.01 $\AA$ or four isothiocyanato ligands and two additional neutral amine-based ligands. The average $\mathrm{Cr}-\mathrm{N}_{\mathrm{amine}}$ bond length equals $2.08 \AA$. The bond lengths are in good agreement with those found in other complexes with comparable complex anions [31-33,60-63]. The presence of extended hydrogen-bonding networks further influences the bond angles (see Table 3).

All angles and bond lengths within the methylimidazolium-based cations (RMIm) $)^{+}$ ( $R$ = methyl, ethyl, n-butyl, benzyl) are in accordance with values reported in the literature for the corresponding substances (DMIm) $\left[\mathrm{Co}(\mathrm{NCO})_{4}\right][24],(\mathrm{EMIm})\left[\mathrm{MBr}_{3} L\right](M=\mathrm{Co}$ : $L=$ quinoline; $M=\mathrm{Ni}: L=$ quinoline, $\mathrm{N}$-methylbenzimidazole, $\mathrm{N}$-methylimidazole, $\left.\mathrm{PPh}_{3}\right)[25,28],(\mathrm{EMIm})\left[\mathrm{Cr}(\mathrm{NCS})_{4}\left(\mathrm{NH}_{3}\right)_{2}\right]$ and $(\mathrm{BMIm})\left[\mathrm{Cr}(\mathrm{NCS})_{4} L\right](L=1,10$-phenanthroline, 2,2'-bipyridine) [31-33], or (BenzMIm) $\left[\mathrm{PF}_{6}\right]$ and (BenzMIm) $\mathrm{Cl} \cdot 0.25 \mathrm{H}_{2} \mathrm{O}$ [64,65], respectively.

\section{Conclusions}

The subclass of ionic liquids bearing Reineckate-derived complex anions (Reinecke's salt, $\left.\left(\mathrm{NH}_{4}\right)\left[\mathrm{Cr}(\mathrm{NCS})_{4}\left(\mathrm{NH}_{3}\right)_{2}\right] \cdot \mathrm{H}_{2} \mathrm{O}\right)$ could be successfully extended to substances of the general formula $(R M I m)_{x}\left[\mathrm{Cr}(\mathrm{NCS})_{4} L_{2}\right](R=$ methyl, ethyl, $\mathrm{n}$-butyl, benzyl; $\mathrm{x}=3: L=\mathrm{NCS} ; \mathrm{x}=1$ : $L=$ Pyr, Pic). The homoleptic triply charged salts of the general formula $(R M I m)_{3}\left[\mathrm{Cr}(\mathrm{NCS})_{6}\right]$ exhibit relatively low melting points and can be transferred into the liquid state without decomposition. These model substances could find a broader application in $\mathrm{Cr}$ (III)-based catalytic transformations (e.g., olefin polymerizations or tri- and tetramerization reaction, respectively). Comparable $(R \mathrm{MIm})\left[\mathrm{Cr}(\mathrm{NCS})_{4} L_{2}\right]$ complexes have shown that they undergo decomposition by the release of amine ligands upon melting. The melting points are almost $100 \mathrm{~K}$ higher than the melting point of the comparable $(R \mathrm{MIm})_{3}\left[\mathrm{Cr}(\mathrm{NCS})_{6}\right]$ compounds. Thorough single-crystal $\mathrm{X}$-ray investigations revealed that the substances are designated by extended hydrogen contact networks in the solid state, whereas additional anion-anion contacts are present in the respective $(R \mathrm{MIm})\left[\mathrm{Cr}(\mathrm{NCS})_{4}(\mathrm{Pic})_{2}\right]$ compounds. This is the first example of such behavior to be reported for this subclass of Reineckate-related substances.

Author Contributions: Conceptualization, T.P. and M.K.; Methodology, T.P. and M.K.; Software, M.K.; Validation, T.P. and M.K.; Formal analysis, T.P. and M.K.; Investigation, T.P.; Resources, M.K.; Data curation, M.K.; Writing—original draft preparation, T.P.; Writing—review and editing, M.K.; Visualization, T.P. and M.K.; Supervision, M.K.; Project administration, M.K.; Funding acquisition, M.K. All authors have read and agreed to the published version of the manuscript.

Funding: This research was funded by the Deutsche Forschungsgemeinschaft (DFG) within the priority program SPP 1191-Ionic Liquids-grant number (KO1616-4).

Data Availability Statement: Crystallographic data can be obtained free of charge from the Cambridge Crystallographic Data Center: CCDC 1988743 for (DMIm) ${ }_{3}$ [Cr(NCS) 6 , CCDC 1988745 for $(\mathrm{EMIm})_{3}\left[\mathrm{Cr}(\mathrm{NCS})_{6}\right]$, CCDC 1988741 for (BenzMIm) $)_{3}\left[\mathrm{Cr}(\mathrm{NCS})_{6}\right]$, CCDC 1988742 for (BMIm) $\left[\mathrm{Cr}(\mathrm{NCS})_{4}(\mathrm{Pyr})_{2}\right]$, and CCDC 1988744 for $(\mathrm{EMIm})\left[\mathrm{Cr}(\mathrm{NCS})_{4}(\mathrm{Pic})_{2}\right]$.

Acknowledgments: The authors thank C. Wulf (LIKAT) and A. Weihs (University of Rostock) for additional DSC and TG measurements. The publication of this article was funded by the Open Access Fund of the Leibniz Association.

Conflicts of Interest: The authors declare no conflict of interest.

\section{References}

1. Gomes, J.M.; Silva, S.S.; Reis, R.L. Biocompatible ionic liquids: Fundamental behaviours and applications. Chem. Soc. Rev. 2019, 48, 4317-4335. [CrossRef] [PubMed]

2. Hallett, J.P.; Welton, T. Room-Temperature Ionic Liquids: Solvents for Synthesis and Catalysis. 2. Chem. Rev. 2011, 111, 3508-3576. [CrossRef]

3. Hayes, R.; Warr, G.G.; Atkin, R. Structure and Nanostructure in Ionic Liquids. Chem. Rev. 2015, 115, 6357-6426. [CrossRef] [PubMed]

4. Sheldon, R. Catalytic reactions in ionic liquids. Chem. Commun. 2001, 2399-2407. [CrossRef] [PubMed]

5. Welton, T. Room-Temperature Ionic Liquids. Solvents for Synthesis and Catalysis. Chem. Rev. 1999, 99, 2071-2084. [CrossRef] 
6. De Frémont, P.; Marion, N.; Nolan, S.P. Carbenes: Synthesis, properties, and organometallic chemistry. Coord. Chem. Rev. 2009, 253, 862-892. [CrossRef]

7. Hahn, F.E.; Jahnke, M.C. Heterocyclic Carbenes: Synthesis and Coordination Chemistry. Angew. Chem. Int. Ed. 2008, 47, 3122-3172. [CrossRef] [PubMed]

8. Hopkinson, M.N.; Richter, C.; Schedler, M.; Glorius, F. An overview of N-heterocyclic carbenes. Nature 2014, 510, 485-496. [CrossRef]

9. Clark, K.D.; Nacham, O.; Purslow, J.A.; Pierson, S.A.; Anderson, J.L. Magnetic ionic liquids in analytical chemistry: A review. Anal. Chim. Acta 2016, 934, 9-21. [CrossRef] [PubMed]

10. Joseph, A.; Żyła, G.; Thomas, V.I.; Nair, P.R.; Padmanabhan, A.S.; Mathew, S. Paramagnetic ionic liquids for advanced applications: A review. J. Mol. Liq. 2016, 218, 319-331. [CrossRef]

11. Santos, E.; Albo, J.; Irabien, A. Magnetic ionic liquids: Synthesis, properties and applications. RSC Adv. 2014, 4, 40008-40018. [CrossRef]

12. Yoshida, Y.; Saito, G. Design of functional ionic liquids using magneto- and luminescent-active anions. Phys. Chem. Chem. Phys. 2010, 12, 1675-1684. [CrossRef]

13. Lozano, P. (Ed.) Sustainable Catalysis in Ionic Liquids, 1st ed.; CRC Press: Boca Raton, FL, USA, 2019.

14. De Vicente, J.; Klingenberg, D.J.; Hidalgo-Alvarez, R. Magnetorheological fluids: A review. Soft Matter 2011, 7, 3701-3710. [CrossRef]

15. Guerrero-Sanchez, C.; Lara-Ceniceros, T.; Jimenez-Regalado, E.; Raşa, M.; Schubert, U.S. Magnetorheological Fluids Based on Ionic Liquids. Adv. Mater. 2007, 19, 1740-1747. [CrossRef]

16. Abdul-Sada, A.A.K.; Al-Juaid, S.; Greenway, A.M.; Hitchcock, P.B.; Howells, M.J.; Seddon, K.R.; Welton, T. Upon the hydrogenbonding ability of the $\mathrm{H} 4$ and $\mathrm{H} 5$ protons of the imidazolium cation. Struct. Chem. 1990, 1, 391-394. [CrossRef]

17. Chongmin, Z.; Takehiko, S.; Akiko, J.-K.; Emiko, F.; Akiko, K.; Mizuki, T.; Yasuhiro, I. Syntheses, Structures, and Properties of a Series of Metal Ion-Containing Dialkylimidazolium Ionic Liquids. Bull. Chem. Soc. Jpn. 2007, 80, 2365-2374. [CrossRef]

18. Hitchcock, P.B.; Seddon, K.R.; Welton, T. Hydrogen-bond acceptor abilities of tetrachlorometalate(II) complexes in ionic liquids. J. Chem. Soc. Dalton Trans. 1993, 2639-2643. [CrossRef]

19. Kozlova, S.A.; Verevkin, S.P.; Heintz, A.; Peppel, T.; Köckerling, M. Paramagnetic Ionic Liquid 1-Butyl-3-methylimidazolium Tetrabromidocobaltate(II): Activity Coefficients at Infinite Dilution of Organic Solutes and Crystal Structure. J. Chem. Eng. Data 2009, 54, 1524-1528. [CrossRef]

20. Zeller, A.; Herdtweck, E.; Strassner, T. 3,3'-Dimethyl-1,1'-methylenediimidazolium tetrachlorocobaltate(II). Acta Crystallogr. Sect. C 2005, 61, m46-m47. [CrossRef]

21. Lee, C.K.; Peng, H.H.; Lin, I.J.B. Liquid Crystals of N,N'-Dialkylimidazolium Salts Comprising Palladium(II) and Copper(II) Ions. Chem. Mater. 2004, 16, 530-536. [CrossRef]

22. Sun, H.; Harms, K.; Sundermeyer, J. The crystal structure of a metal-containing ionic liquid: A new octachlorotricuprate(II). Z. Krist. Cryst. Mater. 2005, 220, 42-44. [CrossRef]

23. Palgunadi, J.; Kwon, O.S.; Lee, H.; Bae, J.Y.; Ahn, B.S.; Min, N.-Y.; Kim, H.S. Ionic liquid-derived zinc tetrahalide complexes: Structure and application to the coupling reactions of alkylene oxides and $\mathrm{CO}_{2}$. Catal. Today 2004, 98, 511-514. [CrossRef]

24. Peppel, T.; Hinz, A.; Thiele, P.; Geppert-Rybczyńska, M.; Lehmann, J.K.; Köckerling, M. Synthesis, Properties, and Structures of Low-Melting Tetraisocyanatocobaltate(II)-Based Ionic Liquids. Eur. J. Inorg. Chem. 2017, 2017, 885-893. [CrossRef]

25. Peppel, T.; Köckerling, M. Investigations on a Series of Ionic Liquids Containing the $\left[\mathrm{CoIIBr}_{3} \text { quin }\right]^{-}$Anion (quin $=$quinoline). Cryst. Growth Des. 2011, 11, 5461-5468. [CrossRef]

26. Peppel, T.; Köckerling, M.; Geppert-Rybczyńska, M.; Ralys, R.V.; Lehmann, J.K.; Verevkin, S.P.; Heintz, A. Low-Viscosity Paramagnetic Ionic Liquids with Doubly Charged $\left[\mathrm{Co}(\mathrm{NCS})_{4}\right]^{2-}$ Ions. Angew. Chem. Int. Ed. 2010, 49, 7116-7119. [CrossRef] [PubMed]

27. Peppel, T.; Köckerling, M. Salts with the 1,3-Dibutyl-2,4,5-trimethyl-imidazolium Cation: $(\mathrm{DBTMIm}) \mathrm{X}(\mathrm{X}=\mathrm{Br}$, PF6) and (DBTMIm $)_{2}\left[\mathrm{MBr}_{4}\right](\mathrm{M}=\mathrm{Co}, \mathrm{Ni})$. Z. Anorg. Allg. Chem. 2010, 636, 2439-2446. [CrossRef]

28. Peppel, T.; Hinz, A.; Köckerling, M. Salts with the $\left[\mathrm{NiBr}_{3}(\mathrm{~L})\right]^{-}$complex anion $(\mathrm{L}=1$-methylimidazole, 1-methylbenzimidazole, quinoline, and triphenylphosphane) and low melting points: A comparative study. Polyhedron 2013, 52, 482-490. [CrossRef]

29. Peppel, T.; Geppert-Rybczyńska, M.; Neise, C.; Kragl, U.; Köckerling, M. Low-Melting Manganese(II)-Based Ionic Liquids: Syntheses, Structures, Properties and Influence of Trace Impurities. Materials 2019, 12, 3764. [CrossRef]

30. Peppel, T.; Kockerling, M. Poly[1-ethyl-3-methylimidazolium [tri-[mu]-isothiocyanato-manganate(II)]]. IUCrData 2019, 4, x191659. [CrossRef]

31. Peppel, T.; Schmidt, C.; Köckerling, M. Synthesis, Properties, and Structures of Salts with the Reineckate Anion, [CrIII(NCS $\left.)_{4}\left(\mathrm{NH}_{3}\right)_{2}\right]^{-}$, and Large Organic Cations. Z. Anorg. Allg. Chem. 2011, 637, 1314-1321. [CrossRef]

32. Peppel, T.; Thiele, P.; Köckerling, M. Low-melting salts with the [CrIII(NCS $)_{4}\left(1,10\right.$-phenanthroline) ${ }^{-}$complex anion: Syntheses, properties, and structures. Russ. J. Coord. Chem. 2012, 38, 207-218. [CrossRef]

33. Peppel, T.; Thiele, P.; Tang, M.-B.; Zhao, J.-T.; Köckerling, M. Low-Melting Imidazolium-Based Salts with the Paramagnetic Reineckate-Analogue Anion $\left[\mathrm{Cr}(\mathrm{NCS})_{4}(\text { bipy) }]^{-}\right.$(bipy = 2,2'-Bipyridine): Syntheses, Properties, and Structures. Inorg. Chem. 2015, 54, 982-988. [CrossRef] [PubMed]

34. Morland, J. XXII.-Notice of a new ammonio-chrome compound. Q. J. Chem. Soc. Lond. 1861, 13, 252-254. [CrossRef] 
35. Nordenskjöld, O. Über die Rhodanide einiger ammoniakalischer Chromverbindungen. Z. Anorg. Chem. 1892, 1, 126-143. [CrossRef]

36. Werner, A.; Richter, G. Beitrag zur Konstitution anorganischer Verbindungen. X. Mitteilung. Über ammoniakalische Chromsulfocyanverbindungen und Stereoisomerie bei denselben. Z. Anorg. Chem. 1897, 15, 243-277. [CrossRef]

37. Bratulescu, G.; Ganescu, I. Chromium (III) complexes anions in the chemical analysis. Anafranile determination. South. Braz. J. Chem. 2007, 15, 49-57.

38. Ganescu, I.; Preda, M. Thiocyanatochromium (III) complexes in chemical analysis. Part 52. Volumetric and spectrophotometric determination of chlorpyramine with tetrathiocyanatodiamine chromates. Pharmazie 1990, 45, 438-439.

39. Mainusch, B.; Karocki, A.; Guldi, D.M.; Stasicka, Z.; Wasgestian, F. Charge transfer photochemistry of Reinecke's salt and of some of its analogues containing organic amines. Inorg. Chim. Acta 1997, 255, 87-93. [CrossRef]

40. Wegner, E.E.; Adamson, A.W. Photochemistry of Complex Ions. III. Absolute Quantum Yields for the Photolysis of Some Aqueous Chromium(III) Complexes. Chemical Actinometry in the Long Wavelength Visible Region. J. Am. Chem. Soc. 1966, 88, 394-404. [CrossRef]

41. Ganescu, I.; Varhelyi, C.; Brinzan, G. Thiocyanatochromium(III) complexes in chemical analysis. 35. Determination of bismuth with thiocyanatochromium(III) complexes. Mikrochim. Acta 1977, 1, 139-144.

42. Gănescu, I.; Várhelyi, C.; Brinzan, G. Thiocyanato-Chrom(III)-Komplexe mit Pilocarpin und die analytische Bestimmung dieses Alkaloids. Arch. Pharm. 1976, 309, 887-892. [CrossRef]

43. Turner, S.S.; Le Pevelen, D.; Day, P.; Prout, K. TTF based charge transfer salts of [Cr(NCS)4(phen)]-: Bulk magnetic order and crystal structures of the TTF, TMTTF (tetramethyltetrathiafulvalene) and TMTSF (tetramethyltetraselenafulvalene) derivatives. J. Chem. Soc. Dalton Trans. 2000, 2739-2744. [CrossRef]

44. Apex-2, v. 1.6-8, Saint, v. 6.25a, SADABS—Software for the CCD Detector System; Bruker-Nonius: Madison, WI, USA, 2003.

45. Sheldrick, G.M. SADABS. Program for Empirical Absorption Correction; University of Göttingen: Göttingen, Germany, 1996.

46. Sheldrick, G. A short history of SHELX. Acta Crystallogr. Sect. A 2008, 64, 112-122. [CrossRef] [PubMed]

47. Haider, J.; Kunz, K.; Scholz, U. Highly Selective Copper-Catalyzed Monoarylation of Aniline. Adv. Synth. Catal. 2004, 346, 717-722. [CrossRef]

48. Huddleston, J.G.; Visser, A.E.; Reichert, W.M.; Willauer, H.D.; Broker, G.A.; Rogers, R.D. Characterization and comparison of hydrophilic and hydrophobic room temperature ionic liquids incorporating the imidazolium cation. Green Chem. 2001, 3, 156-164. [CrossRef]

49. Namboodiri, V.V.; Varma, R.S. Solvent-Free Sonochemical Preparation of Ionic Liquids. Org. Lett. 2002, 4, 3161-3163. [CrossRef]

50. Nishida, T.; Tashiro, Y.; Yamamoto, M. Physical and electrochemical properties of 1-alkyl-3-methylimidazolium tetrafluoroborate for electrolyte. J. Fluor. Chem. 2003, 120, 135-141. [CrossRef]

51. Oertel, A.M.; Ritleng, V.; Burr, L.; Chetcuti, M.J. Synthesis and Structural Characterization of Half-Sandwich Nickel Complexes Bearing Two Different N-Heterocyclic Carbene Ligands. Organometallics 2011, 30, 6685-6691. [CrossRef]

52. Roesler, J. Ueber einige Chromidschwefelcyanverbindungen. Justus Liebigs Ann. Chem. 1867, 141, 185-197. [CrossRef]

53. Brauer, G. (Ed.) Potassium Hexathiocyanatochromate (III). In Handbook of Preparative Inorganic Chemistry, 2nd ed.; Academic Press: New York, NY, USA, 1965; Volume 2, p. 1374.

54. Peppel, T.; Wulf, C.; Spannenberg, A. 1-Benzyl-3-methylimidazolium bromide. IUCrData 2020, 5, 200768. [CrossRef]

55. Pfeiffer, P. Tetrarhodanato-dipyridin-chromsalze. Ber. Dtsch. Chem. Ges. 1906, 39, 2115-2125. [CrossRef]

56. Ripan, R.; Gånescu, I.; Várhelyi, C. Neue Substitutionsprodukte von $\mathrm{K}_{3}\left[\mathrm{Cr}(\mathrm{NCS})_{6}\right]$ mit einigen heterocyclischen N-Basen. Z. Anorg. Allg. Chem. 1968, 357, 140-148. [CrossRef]

57. Gade, L.H. Grundlagen der Kristall-/Ligandenfeldtheorie. In Koordinationschemie; Wiley-VCH: Weinheim, Germany, 2013; pp. 183-241. [CrossRef]

58. Bennett, M.A.; Clark, R.J.H.; Goodwin, A.D.J. Electronic and infrared spectral study of chromium (III) derivatives of the type [Cr(NCS $)_{4}$.(ligand $)_{2}$ ]. Inorg. Chem. 1967, 6, 1625-1631. [CrossRef]

59. Saielli, G.; Satoh, K. A coarse-grained model of ionic liquid crystals: The effect of stoichiometry on the stability of the ionic nematic phase. Phys. Chem. Chem. Phys. 2019, 21, 20327-20337. [CrossRef] [PubMed]

60. Savard, D.; Leznoff, D.B. Synthesis, structure and light scattering properties of tetraalkylammonium metal isothiocyanate salts. Dalton Trans. 2013, 42, 14982-14991. [CrossRef] [PubMed]

61. Morsing, T.J.; Weihe, H.; Bendix, J. Synthesis, Characterisation and Modelling of a Ferromagnetically Coupled Chromium(III) Dimer: Di- $\mu$-hydroxobis[tetrakis(isothiocyanato)chromate(III)]. Eur. J. Inorg. Chem. 2014, 2014, 5990-5996. [CrossRef]

62. Kitanovski, N.; Golobic, A.; Ceh, B. Preparation and crystal structures of trans-K[Cr(NCS $\left.)_{4} \mathrm{py}_{2}\right] \cdot 4 \mathrm{py}$ and mer-[Cr(NCS $)_{3}(\gamma-$ pic) $\left.)_{3}\right] \cdot 4 / 3$ ( $\gamma$-pic). Croat. Chem. Acta 2007, 80, 127-134.

63. Brooks, A.C.; Martin, L.; Day, P.; Clegg, W.; Harrington, R.W.; Wallis, J.D. New crystal packing arrangements in radical cation salts of BEDT-TTF with $\left[\mathrm{Cr}(\mathrm{NCS})_{6}\right]^{3-}$ and $\left[\mathrm{Cr}(\mathrm{NCS})_{5}\left(\mathrm{NH}_{3}\right)\right]^{2-}$. Polyhedron 2015, 102, 75-81. [CrossRef]

64. Hillesheim, P.C.; Scipione, K.A. Crystal structure of 1-benzyl-3-methyl-1H-imidazolium hexafluoridophosphate. Acta Crystallogr. Sect. E 2014, 70, o1248-o1249. [CrossRef]

65. Ji, X.; Cheng, B.; Song, J.; Liu, C. 1-Benzyl-3-methylimidazolium chloride 0.25-hydrate. Acta Crystallogr. Sect. E 2010, 66, o218. [CrossRef] 